\title{
LIVE MASS, WATER CONTENT, NITROGEN AND MINERAL LEVELS IN SOME INSECTS FROM SOUTH-CENTRAL LOWER MICHIGAN
}

\author{
Eugene H. Studier and Steven H. Sevick \\ Department of Biology, University of Michigan-Flint, Flint, MI 48502-2186, U.S.A. (Tel. 313-762-3360)
}

(Received 16 March 1992; accepted 15 April 1992)

\begin{abstract}
Live and dry mass, water content, nitrogen, sodium, potassium, magnesium, calcium and total iron concentrations are reported (or are available from the authors or the Faculty/Staff Collcction of The University of Michigan-Flint Library) for members of 16 orders (360 species) of mostly adult, flying insects from south-central lower Michigan.

2. Compared to published nutritional requirements (when meeting caloric requirements) for growth and reproduction in birds and mammals, insects are excellent sources of nitrogen, potassium and magnesium, highly variable sources of sodium and iron, and, very rarely, adequate calcium sources.

3. Elemental composition of some insects differs by size, sex, season and after culling.
\end{abstract}

\section{INTRODUCTION}

The question, 'why do animals eat what they eat?' has generated extreme interest among biologists. Such studies fall generally within the category of optimal foraging theory (for example, see Schoener, 1971, 1979; Krebs, 1978, 1980; Pyke et al., 1977; Pyke, 1984), and include concepts of time-minimizing and energy-maximizing feeding strategies, of opportunistic and selective feeding habits, as well as generating and testing descriptive foraging models (for example, see Belovsky, 1981, 1984; Belovsky et al., 1989; Clark, 1982; Vickery, 1984). Those studies are predicated on appropriate, or at least adequate, dietary nutrient self-selection and nutrient availability, and those assumptions have been questioned (Sullivan, 1988, 1989; Beck and Galef, 1989; Galef, 1991).

Insects are consumed as dietary items by an extremely wide variety of vertebrates, including bats (Gardner 1977; Whitaker, 1988) and birds (Ehrlich et al., 1988). Estimation of nutritional budgets of animals requires quantification of amounts and composition of foods eaten and of resultant wastes. Estimates of energy (= caloric or carbon) demands or budgets and factors affecting those requirements have been reported for a wide variety of animals (for review, see Peters, 1983). The focus of most studies on caloric aspects of energy budgets seems reasonable, since growth and reproduction in individuals and populations require long-term maintenance of positive caloric budgets. Associated with the concentration of such caloric budgets, many reports are available concerned with energy content of foodstuffs, including insects (for example, see Cummins and Wuycheck, 1971; Schroeder, 1977; Slansky and Scriber, 1985).

Emphasis on examination of energy budgets implies that, in maintaining those budgets, animals automatically satisfy their remaining nutrient requirements. Except for the unlikely or unusual ingestion of "perfect" food that contains adequate levels of all other required macromolecules, water, vitamins, elements, etc., ingestion of enough calories to meet or slightly exceed energy demands would rarely provide sufficient intake of all nutrients. Within the perview of optimal foraging theory, some consideration has been given to dietary optimization when specific nutrient constraints are important (Pulliam, 1975; Stamps et al., 1981). If intake of a specific nutrient impacts foraging strategies, then some dietary choices must be inadequate in concentration for such limiting nutrients and other selected dietary items must contain adequate or excessive levels of said nutrient.

Other than caloric content and associated measures of live mass and water content, rarity of published data on insect mineral composition (reviewed by Mattson and Scriber, 1987) precludes expansion of nutritional budget studies of insectivorous animals to include other nutrient budgets and application of optimal foraging models based on non-caloric nutrient constraints. Lack of published data, coupled with availability of new technology, has prompted the present study.

While data on caloric and water requirements are available for a wide variety of organisms (Peters, 1983), requirements for other nutrients, e.g. nitrogen and minerals, are restricted to commonly studied small laboratory mammals and commercially important birds (National Research Council, 1978, 1984).

Some insect-eaters, especially bats (Bell, 1982), cull food items, and limited data are reported here on nutritional composition of whole versus culled individuals of a few insect species. Limited mineral composition data on insects indicate possible differences with year, season, size, age and gender (Reichle et al., 1969; Levy and Cromroy, 1973; Schowalter et al., 1981; Bowden et al., 1984) and possible effects of these variables are briefly investigated.

Since we are concerned with insects as prey of aerial insectivores, we present data on live and dry mass, water content, nitrogen, sodium, potassium, 
magnesium, calcium and total iron content of whole, primarily flying, insects found in south-central lower Michigan.

\section{MATERIALS AND METHODS}

Except for periodical cicadas (collected near Chicago, IL, and sent to us, alive, via air express by Dr Thomas Poulson), all insects were collected from Genesee, Livingston, Shiawasee or Lapeer Counties in south-central lower Michigan from March through October 1990. Although a wide variety of collection sites for day-active insects were utilized, most collections were made in two county parks in Genesee Co., MI. Most day collections were made with hand nets. Night-active insects were primarily collected at seven different sites; however, repetitive (at 1-2 week intervals) night collections were made at two sites located within $500 \mathrm{~m}$ of maternity roosts of big brown bats, Eptesicus fuscus. One site was in an uncut hay field in rural Livingston Co., MI, and the other site was adjacent to the Shiawasee River within the city limits of Byron, Shiawasee Co., MI. Night-active insects were attracted to one of three light traps (white bed sheets stretched over A-frames) containing incandescent, ultraviolet ("blacklight"), or mercury vapor lamps.

All insects were placed in air-tight plastic vials during or immediately after collection. Vials were placed on ice, returned to the laboratory and frozen until identification and analysis began. Except for eastern tent moth caterpillars, Malacosoma americanum (Studier et al., 1991), no immature individuals of any species that exhibits complete metamorphosis were collected. Immature grasshoppers, crickets, box elder bugs and spittlebugs were deliberately collected to determine if any relationships exist between insect size and elements measured. Box elder bugs were collected in three months (March $=$ spring, June = summer and Octoher $=$ fall) to determine if any measured elements varied with season. Finally, since bats often cull their prey before consuming it, some individuals of some abundant species (May beetles, periodic cicadas and one moth) were studied both whole and culled (legs, wings, elytra, if present, and heads removed).

Individuals were identified utilizing various sources (Blatchley, 1920; Cantrall, 1943, 1968; Needham and Westfall, 1955; Gurney and Brooks, 1959; Leonard and Leonard, 1962; Edmunds and Jensen, 1976; Milne and Milne, 1980; Pyle, 1981; McCafferty, 1981; White, 1983; Covell, 1984; Arnett, 1985), as well as local reference collections of some groups (obtained from The Museum, University of Michigan, Ann Arbor). Nomenclature generally follows Arnett (1985). Insects were sexed, whenever possible, aged as adults or immatures, and sex, if known, age, and collection data were recorded. Voucher specimens of all species collected in large numbers have been deposited at The Museum, University of Michigan, Ann Arbor, or retained by the authors.

Immediately upon thawing, individual or small groups of identified insects were weighed (to nearest $0.1 \mathrm{mg}$ ), placed in new aluminum weighing dishes and dried to constant weight at $5060^{\circ} \mathrm{C}$. Body water content was determined by difference. Although precautions were taken to prevent desiccation before initial weights were taken, some drying may have occurred and water content, especially of small insects, may be somewhat underestimated. In cases where collected insects were known to be partially desiccated, data on live weight and water content are omitted.

Weighed, identified, dry, whole insects were wet oxidized in a cleaned volumetric flask in boiling, concentrated $\mathrm{H}_{2} \mathrm{SO}_{4}$, followed by addition of a mixture of $30 \%$ $\mathrm{H}_{2} \mathrm{O}_{2}$ : concentrated $\mathrm{H}_{2} \mathrm{SO}_{4}(2: 1 \mathrm{v} / \mathrm{v})$. After digestion was complete, cooled samples were diluted to flask volume. Amounts used were dependent on original dry sample weight. Dry samples weighing from 10 to $35 \mathrm{mg}$ were digested in $25 \mathrm{ml}$ volumetric flasks with $0.25 \mathrm{ml}$ concentrated $\mathrm{H}_{2} \mathrm{SO}_{4}$ and $0.75 \mathrm{ml}$ of mixture; dry samples weighing between 35 and $150 \mathrm{mg}$ were digested in $100 \mathrm{ml}$ volumetric flasks with $1 \mathrm{ml}$ of concentrated $\mathrm{H}_{2} \mathrm{SO}_{4}$ and $3 \mathrm{ml}$ of mixture; and, dry samples weighing more than $150 \mathrm{mg}$ were digested to $250 \mathrm{ml}$ volumetric flasks with $2.5 \mathrm{ml} \mathrm{H}_{2} \mathrm{SO}_{4}$ and $7.5 \mathrm{ml}$ of mixture. For very small insects, individuals were grouped to obtain minimum $10 \mathrm{mg}$ samples. Each diluted sample was kept in a new, non-sterile, leakproof, $120 \mathrm{ml}$ capacity, clear, polypropylene, screw-capped container (Fisher Scientific, Itasca, IL). One milliliter aliquots of diluted samples were analysed for nitrogen content by Nesslerization (Treybig and Haney, 1983). Additional aliquots, after appropriate dilution and preparation, were analysed for sodium, potassium, magnesium, calcium and total iron concentrations following standard procedures using a Varian Spectra AA20 atomic absorption spectrophotometer (analytical methods for flame spectroscopy, Varian Techtron Pty. Ltd, Springvale, Australia). Sodium and potassium levels were determined by flame emission and all other minerals by atomic absorption. Required dilutions of each sample were performed with the aid of an Eppendorf Digital Pipette (Brinkmann Instruments Co., Westbury, New York) and FISHERbrand Adjustable Dispensers (Fisher Scientific, Pittsburg, PA) into new, non-sterile, $12 \times 75 \mathrm{~mm}$, clear, polystyrene tubes and covered with PARAFILM (American National Can, Greenwich, CT). All diluted samples were analysed within $48 \mathrm{hr}$ of dilution and all samples were mixed by inversion just prior to measurement. Water used throughout the determinations was purified by a reverse osmosis system and further purified with a Barnstead NANOpure II water purifying system (Barnstead/ Thermolyne Corp., Dubuque, IA). Volumetric flasks used in digestions were rinsed three times and dried at $50-60^{\circ} \mathrm{C}$ between use. These precautions were necessary due to the extreme sensitivity of atomic absorption spectrophotometry to contaminants.

Values for nitrogen are expressed as per cent $(\%)$ dry weight and all minerals are expressed as parts per thousand (ppt) dry weight. With the weight:volume ratios used in the digestion process in this study, the lower limit of detection for sodium was about 0.001 ppt dry mass and samples that read below that limit are reported as $0(<0.001 \mathrm{ppt})$. Minimum detection limit for total iron was about $0.01 \mathrm{ppt}$ dry mass and samples with lower total iron levels are reported as $0(<0.01 \mathrm{ppt})$. Levels for sodium $\left(\mathrm{Na}^{+}\right)$, potassium $\left(\mathrm{K}^{+}\right)$, magnesium $\left(\mathrm{Mg}^{2+}\right)$ and calcium $\left(\mathrm{Ca}^{2+}\right)$ include only those valence states; however, levels for iron include both common valence states $\left(\mathrm{Fe}^{2+}\right.$ and $\left.\mathrm{Fe}^{3+}\right)$ and are, therefore, reported as total iron.

Data were stored in Lotus files. Data analyses were performed using SYSTAT (Wilkinson, 1987).

\section{RESULTS AND DISCUSSION}

\section{Live weights and water content}

Live (wet) and dry mass, per cent body water, collection dates, sex and element levels for selected species studied are shown in Appendix 1. Complete data sets are available from the authors or from the Faculty/Staff Collection of The University of Michigan-Flint Library in hard copy. Water content in all insec ${ }^{+}>$'cstcd is consistent in the $60-70 \%$ range of live weigh:. Regression analyses of per cent body water vs individual dry weight for Melanoplus spp., $M$. bivittatus, Gryllus pennsylvanicus, Hippiscus rugosa, Leptocoris trivittatus and Philaenus spumarius show significant relationships only in the melanoplines (in $M$. bivittatus, $\mathrm{F}=31.33$, $\mathrm{df}=1$ and 30 , $r^{2}=0.511, P<0.001 ;$ and, in other melanoplines, $\mathrm{F}=18.65$, df $=1$ and $\left.168, r^{2}=0.100, P<0.001\right)$. 
Relations between live mass (LM in $\mathrm{mg}$ ) and per cent body water $(\% \mathrm{BW})$ in $M$. bivittatus and other melanoplines, respectively, are:

$$
\% \text { BW }=-0.022( \pm 0.004) \mathrm{LM}+74.97( \pm 0.75)
$$

and

$$
\% \mathrm{BW}=-0.017( \pm 0.004) \mathrm{LM}+72.47( \pm 0.43)
$$

where values in parentheses are standard errors of the means. The group designated Melanoplus spp. includes, at least, $\boldsymbol{M}$. confusus, $\boldsymbol{M}$. borealis and $\boldsymbol{M}$. fenurrubrum. Some of the variation in percentage boly water may be explained by a slight tendency toward decrease in relative water content with increasing size related to the associated decrease in sur face area: mass ratio with increasing size. Since all ins scts were analysed whole, gut fullness and percentag: water of gut contents would also contribute to valiability in percentage body water. High levels of bo.ly fat, especially in large, gravid females, would contribute to variability by reducing water content and probably contribute to the negative relation found for water content as a function of size ii melanoplines. As can be calculated from the data in Acpendix 1, significant differences in live weight and peicentage body water exist by sex for many species, e.g among the Emphemeroptera, for Baetis spp., live males are heavier than females $(t=6.57, \mathrm{df}=34$, $P=0.001$ ), while for Stenonema pulchellum, live fentales are heavier than males $(\mathrm{t}=2.20, \mathrm{df}=20$, $P<0.05)$

\section{Elemental composition}

Blemental composition of insects studies (summarized by order in Table 1 and by species in Appendix 1) agrees well with the limited data summarized by Mittson and Scriber (1987). Minimal requirements for growth and reproduction in birds for the elements measured are: iron, $0.08-0.10 \mathrm{ppt}$ dry mass (DM); calcium, $6.5-12.0 \mathrm{ppt} \mathrm{DM}$; magnesium, $0.3-0.5 \mathrm{ppt}$ DM; sudium, $1.5-1.7 \mathrm{ppt} D \mathrm{DM}$; potassium, 4.0-7.0 ppt DM; and nitrogen, 3.5-4.8\% DM as ideal or complete protein (National Research Council, 1984). In mammals, these requirements are: iron,
0.025-0.140 ppt DM; calcium, 4.0-8.0 ppt DM; magnesium, 0.4-1.0 ppt DM; sodium $0.5-1.5 \mathrm{ppt} \mathrm{DM}$; potassium, 2.0-7.2 ppt DM; and nitrogen, 1.9-2.09\% DM as protein (National Research Council, 1978). These values represent concentrations of nutrients required in a calorically adequate diet.

As sources of iron, megalopterans appear to be inadequate (small sample size makes this a very tentative conclusion), while walking sticks (Phasmatodea), mantids (Mantodea), lepidopterans and, perhaps even hemipterans and coleopterans, probably provide marginally adequate dietary iron. As previously stated, the procedure used measures total iron (both $\mathrm{Fe}^{2+}$ and $\mathrm{Fe}^{3+}$ ). Iron is assimilated primarily as ferrous ion $\left(\mathrm{Fe}^{2+}\right)$ and, since iron is poorly assimilated (Charlton and Bothwell, 1983), insect species (Appendix 1) containing less than $0.2 \mathrm{ppt}$ may not provide sufficient iron to meet needs for growth and reproduction.

On average, only stone flies (plecopterans) provide sufficient dietary calcium to meet needs for growth and development of birds and mammals. The female Perlesta decipiens studied were gravid and show body calcium concentrations which are significantly higher than in males $(\mathrm{t}=27.64, \mathrm{df}=22, P<0.001)$. Hemipterans may be marginally adequate as calcium sources for mammals. All other insects represent inadequate sources of calcium. The possibility that dietary calcium intake may be a limiting nutrient in insectivorous birds has received some attention based on both nutritional models (Turner, 1982) and observations of the consumption of bone or grit during reproductively active periods (Maclean, 1974; Jones, 1976; Repasky et al., 1991). Based on quite limited data, some other arthropods, e.g. millipedes and isopods, may be excellent dietary calcium sources (Reichle et al., 1969; Carter and Cragg, 1976).

All insects tested are adequate sources of dietary magnesium for birds and mammals except for hymenopterans, which may be marginal for mammals.

As sources of dietary sudium for birds, phasmatids, orthopterans, mantids, homopterans, neuropterans, trichopterans, hymenopterans and lepidopterans are inadequate and coleopterans are marginal. For mam.

\begin{tabular}{|c|c|c|c|c|c|c|c|c|c|}
\hline Order & Sp & $\begin{array}{c}N \\
(*)\end{array}$ & $\begin{array}{c}\mathrm{DM} \\
(\mathrm{mg})\end{array}$ & $\begin{array}{c}\mathrm{Fe} \\
\text { (ppt) }\end{array}$ & $\underset{(p p t)}{\mathrm{Ca}}$ & $\begin{array}{c}\mathrm{Mg} \\
(\mathrm{ppt})\end{array}$ & $\underset{(p p t)}{\mathrm{Na}}$ & $\underset{(p p t)}{K}$ & $\underset{(\%)}{N}$ \\
\hline Ephemeroptera & 16 & $126(324)$ & $15.2 \pm 1.6$ & $0.332 \pm 0.038$ & $1.024 \pm 0.036$ & $1.211 \pm 0.042$ & $2.698 \pm 0.071$ & $10.15 \pm 0.23$ & $18.04 \pm 0.32$ \\
\hline Odrnata & 20 & $120(153)$ & $34.8 \pm 4.9$ & $0.407 \pm 0.039$ & $0.869 \pm 0.021$ & $1.630 \pm 0.125$ & $3.015 \pm 0.112$ & $9.75 \pm 0.21$ & $18.25 \pm 0.21$ \\
\hline Plecoptera & 5 & $39(124)$ & $17.8 \pm 3.8$ & $0.581 \pm 0.106$ & $11.515 \pm 1.273$ & $2.572 \pm 0.190$ & $1.920 \pm 0.121$ & $7.25 \pm 0.20$ & $17.14 \pm 0.42$ \\
\hline Phasmatodea & 1 & 5 & $83.7 \pm 7.6$ & $0.100 \pm 0.019$ & $2.634 \pm 0.443$ & $2.952 \pm 0.128$ & $0.125 \pm 0.050$ & $14.89 \pm 0.57$ & $14.66 \pm 0.63$ \\
\hline Orthoptera & 18 & $269(300)$ & $99.4 \pm 6.2$ & $0.211 \pm 0.023$ & $1.876 \pm 0.063$ & $1.340 \pm 0.031$ & $0.659 \pm 0.054$ & $12.30 \pm 0.18$ & $16.32 \pm 0.17$ \\
\hline Mantodea & 1 & 7 & $113.6 \pm 14.6$ & $0.143 \pm 0.055$ & $1.815 \pm 0.157$ & $1.366 \pm 0.073$ & $1.336 \pm 0.107$ & $9.23 \pm 0.22$ & $14.34 \pm 0.51$ \\
\hline Dermaptera & 1 & $14(14)$ & $15.4 \pm 1.0$ & $0.702 \pm 0.042$ & $1.595 \pm 0.101$ & $1.284 \pm 0.063$ & $1.757 \pm 0.100$ & $9.52 \pm 0.27$ & $16.71 \pm 0.50$ \\
\hline Heniptera & 10 & $82(185)$ & $46.9 \pm 21.7$ & $0.191 \pm 0.024$ & $3.126 \pm 0.183$ & $2.736 \pm 0.120$ & $2.406 \pm 0.394$ & $13.27 \pm 0.79$ & $18.70 \pm 0.36$ \\
\hline Hotnoptera & 6 & $94(192)$ & $160.8 \pm 28.7$ & $0.563 \pm 0.034$ & $2.271 \pm 0.045$ & $1.804 \pm 0.046$ & $0.581 \pm 0.056$ & $9.43 \pm 0.28$ & $14.40 \pm 0.44$ \\
\hline Netroptera & 1 & $6(13)$ & $5.6 \pm 0.5$ & $0.385 \pm 0.168$ & $2.018 \pm 0.575$ & $1.072 \pm 0.310$ & $0.118 \pm 0.108$ & $13.69 \pm 1.07$ & $16.60 \pm 0.91$ \\
\hline Megaloptera & 1 & 2 & 76.8 & $0 . \overline{034}$ & 1.721 & $1 . \overline{7} 10$ & 2.285 & $9 . \overline{03}$ & 13.08 \\
\hline Col:optera & 43 & $194(236)$ & $47.7 \pm 8.2$ & $0.188 \pm 0.020$ & $1.050 \pm 0.052$ & $1.523 \pm 0.043$ & $1.660 \pm 0.096$ & $9.01 \pm 0.22$ & $16.84 \pm 0.21$ \\
\hline Tric hoptera & 13 & $74(173)$ & $15.6 \pm 1.9$ & $0.338 \pm 0.039$ & $1.793 \pm 0.110$ & $1.149 \pm 0.065$ & $1.412 \pm 0.102$ & $7.12 \pm 0.28$ & $16.77 \pm 0.27$ \\
\hline Hymenoptera & 21 & $135(161)$ & $51.6 \pm 4.4$ & $0.270 \pm 0.025$ & $0.759 \pm 0.036$ & $0.956 \pm 0.023$ & $0.556 \pm 0.051$ & $9.21 \pm 0.30$ & $16.88 \pm 0.26$ \\
\hline Lepidoptera & 181 & $546(597)$ & $45.1 \pm 2.1$ & $0.145 \div 0.009$ & $1.221 \pm 0.041$ & $2.308 \pm 0.068$ & $0.544 \pm 0.055$ & $9.40 \pm 0.13$ & $16.61 \pm 0.13$ \\
\hline Diptera & 20 & $108(474)$ & $10.2 \pm 1.2$ & $0.576 \pm 0.069$ & $1.471 \pm 0.114$ & $1.275 \pm 0.070$ & $2.217 \pm 0.118$ & $8.69 \pm 0.18$ & $17.81 \pm 0.23$ \\
\hline
\end{tabular}

Table 1. Element composition of some insects from south-central lower Michigan

Values for elements are arithmetic means \pm standard errors, $\mathrm{Sp}=$ number of species tested, $N=$ number of samples, $\left({ }^{*}\right)=$ number of individuals tested, if different from number of samples and $\mathbf{D M}=$ dry matter. Units for minerals are parts per thousand (ppt) dry mass and for nitrogen are per cent $(\%)$ dry mass. For Orders in which only one species was tested, those species are: in Phasmatodea, Diapheroma femorato [two females (F), thre males (M)]; in Mantodea, Mantis religiosa (seven F); in Dermaptera, Forficula auricularia (10 F. four M); in Neuroptera, Chrysopa ornata (six, sexes combined); in Megaloptera, Chauliodes rastiicornis (two, sexes unknown). 
Table 2. Significant linear relationships for body element (E) levels

\begin{tabular}{|c|c|c|c|c|c|c|}
\hline $\mathbf{E}$ & Slope & Intercept & $r^{2}$ & $\mathbf{F}$ & d.f. & $P$ \\
\hline \multicolumn{7}{|c|}{ Melanoplus spp. (DM range $=2.9-597.3 \mathrm{mg}$ ) } \\
\hline $\mathbf{N}$ & $-0.014 \pm 0.002$ & $17.91 \pm 0.28$ & 0.195 & 33.25 & 1,137 & $<0.001$ \\
\hline $\mathbf{K}$ & $-0.005 \pm 0.002$ & $12.66 \pm 0.26$ & 0.037 & 5.32 & 1,137 & 0.023 \\
\hline $\mathbf{M g}$ & $-0.002 \pm 0.001$ & $1.517 \pm 0.06$ & 0.107 & 16.39 & 1,137 & $<0.001$ \\
\hline $\mathrm{Ca}$ & $-0.002 \pm 0.001$ & $2.028 \pm 0.101$ & 0.043 & 6.18 & 1,137 & 0.014 \\
\hline $\mathbf{F e}$ & $-0.002 \pm 0.000$ & $0.371 \pm 0.044$ & 0.127 & 19.95 & 1,137 & $<0.001$ \\
\hline \multicolumn{7}{|c|}{ Melanoplus bivittatus $(\mathrm{DM}$ range $=11.5-489.7 \mathrm{mg}$ ) } \\
\hline $\mathbf{N}$ & $-0.010 \pm 0.003$ & $17.58 \pm 0.54$ & 0.284 & 11.92 & 1,30 & 0.002 \\
\hline K & $-0.011 \pm 0.004$ & $13.80 \pm 0.69$ & 0.210 & 7.99 & 1,30 & 0.008 \\
\hline $\mathbf{M g}$ & $-0.002 \pm 0.001$ & $1.749 \pm 0.125$ & 0.211 & 8.05 & 1,30 & 0.008 \\
\hline \multicolumn{7}{|c|}{ Hippiscus rugosa (DM range $=17.0-540.7 \mathrm{mg}$ ) } \\
\hline $\mathrm{N}$ & $-0.013 \pm 0.002$ & $17.47 \pm 0.52$ & 0.683 & 36.55 & 1,17 & $<0.001$ \\
\hline $\mathbf{K}$ & $0.005 \pm 0.002$ & $10.62 \pm 0.53$ & 0.230 & 5.08 & 1,17 & 0.038 \\
\hline $\mathrm{Fe}$ & $-0.001 \pm 0.000$ & $0.419 \pm 0.087$ & 0.380 & 10.41 & 1,17 & 0.005 \\
\hline \multicolumn{7}{|c|}{ Leptocoris trivittatus (DM range $=1.1-20.5 \mathrm{mg}$ ) } \\
\hline $\mathbf{N}$ & $-0.107 \pm 0.041$ & $19.40 \pm 0.49$ & 0.193 & 6.71 & 1,28 & 0.015 \\
\hline $\mathbf{K}$ & $-0.134 \pm 0.034$ & $13.00 \pm 0.41$ & 0.352 & 15.19 & 1,28 & 0.001 \\
\hline $\mathbf{M g}$ & $-0.065 \pm 0.015$ & $4.313 \pm 0.176$ & 0.404 & 18.98 & 1,28 & $<0.001$ \\
\hline \multicolumn{7}{|c|}{ Philaenus spumarius (DM range $=0.6-3.8 \mathrm{mg}$ ) } \\
\hline $\mathrm{Fe}$ & $-0.016 \pm 0.006$ & $0.073 \pm 0.015$ & 0.376 & 8.44 & 1,14 & 0.012 \\
\hline
\end{tabular}

Nitrogen in \% dry weight; potassium, calcium, magnesium and total iron in part per thousand dry weight, and dry mass (DM) in mg. Values are means \pm standard errors. No significant relationships were found for Gryllus pennsylvanicus.

mals, since their sodium needs are less than those of birds, only phasmatids and lacewings (neuropterans) are inadequate sodium sources and the other groups just listed for birds are all marginal sodium sources for mammals. Among the night-flying geometrid, arctiid and, especially, noctuid moths, which are consumed readily by bats, sodium levels are essentially bimodal with many species containing immeasurably low sodium concentrations while others exhibit extremely high body sodium levels. Some of those moths, therefore, provide no nutritional sodium while others are superb nutritional sodium sources. The extreme variability in sodium level may relate to puddling behavior reported for some lepidopterans (Arms et al., 1974).

With the possible exception of trichopterans, all insects tested provide sufficient dietary potassium to meet the nutritional needs of birds and mammals. Dietary sodium requirements increase with increasing potassium intake in herbivores (Meyer et al., 1950; Weeks and Kirkpatrick, 1978; Staaland et al., 1980) and insects high in potassium, e.g. phasmatids, orthopterans, hemipterans and neuropterans, may, therefore, increase the nutritional minimum for sodium.

Avian and mammalian nitrogen requirements for growth and reproduction given above are values for complete or ideal protein, i.e. all amino acids present. While many plant proteins are incomplete, most proteins of animal origin are complete. Insects, therefore, would seem to be excellent and adequate sources of dietary protein for birds and mammals. Since much of the total nitrogen present in insects, however, is unavailable, e.g. as aminated polysaccharides in the exoskeleton, much of the total nitrogen cannot be assimilated. Dry nitrogen levels, however, exceed dietary requirements by at least a factor of three and it seems unreasonable that less than one-third of the total measured nitrogen is available. Consequently, even with these caveats, insects almost certainly provide adequate required dietary nitrogen.

Significant linear regression relationships found with size for nitrogen and minerals are given in Table 2. Of the species tested, only the crickets,
Gryllus pennsylvanicus, showed no relationships of mass to any of the elements tested. That lack of relationships in crickets may well be attributed to the considerable variability in crop fullness found in the individuals tested. The observance of a significant relationship for just one element $(\mathrm{Fe})$ to size in spittlebugs may relate to the small size range available for testing. No relationship was found for $\mathrm{Na}^{+}$ level and body mass in any species tested, and $\mathrm{Ca}^{2+}$ was significantly related to size in only the melanoplines. Relationships to size were found for at least half of the species tested for the remaining elements ( $\mathrm{N}, \mathrm{K}, \mathrm{Mg}$ and $\mathrm{Fe}$ ). Nearly all significant linear relationships have negative slopes which, again, imply a surface area:mass decrease with size phenomenon; however, most relationships have quite low coefficients of determination $\left(r^{2}\right)$ which indicates that although elemental variation is related to body size, characteristics other than size have marked influence on elemental variation. Factors other than crop fullness, which might explain the observed variability in elemental composition, include combining species during classification of the melanoplines, gender differences, differences in collection sites or seasons which modify available foodstuffs for insects, and ages of tested insects which show incomplete metamorphosis. Elemental composition of insects that exhibit complete metamorphosis has also been reported to differ with developmental stage (Levy and Cromroy, 1973; Studier et al., 1991).

The possible importance of sex and season on mass and elemental composition are demonstrated by data on box elder bugs (Leptocoris trivittatus) shown in Table 3. The high coefficients of determination suggest that, at least in this species, both sex and season strongly affect elemental composition. Such seasonal and gender composition differences have been previously reported for a few insects (Reichle et al., 1969; Bowden et al., 1984).

Culling generally removes body parts which contain slightly lower water content, such as elytra, wings, legs and the head; and culled individuals may, therefore, have a slightly higher percentage of water 
Table 3. Dry mass (DM, mg), N (\% DM) and mineral (ppt DM) levels in box elder bugs, Leptocoris trivittatus, by sex and season

\begin{tabular}{|c|c|c|c|c|c|c|c|c|c|}
\hline Mo & $\mathbf{S}$ & $\mathbf{N}$ & DM & $\mathrm{Fe}$ & $\mathrm{Ca}$ & $\mathbf{M g}$ & $\mathrm{Na}$ & $\mathbf{K}$ & $\mathbf{N}$ \\
\hline $\mathbf{M r}$ & $\mathbf{F}$ & $5(15)$ & $16.3 \pm 0.9$ & $0.158 \pm 0.024$ & $1.339 \pm 0.042$ & $3.061 \pm 0.081$ & $0.916 \pm 0.181$ & $21.22 \pm 1.75$ & $19.74 \pm 0.74$ \\
\hline $\mathbf{M r}$ & $\mathbf{M}$ & $4(16)$ & $8.2 \pm 0.3$ & $0.189 \pm 0.024$ & $1.907 \pm 0.027$ & $3.425 \pm 0.140$ & $0.663 \pm 0.164$ & $13.00 \pm 0.52$ & $22.42 \pm 0.50$ \\
\hline $\mathrm{Jn}$ & $\mathbf{F}$ & 5 & $14.7 \pm 1.4$ & $0.016 \pm 0.004$ & $3.348 \pm 0.265$ & $3.486 \pm 0.357$ & $0.663 \pm 0.084$ & $11.60 \pm 0.56$ & $17.84 \pm 0.38$ \\
\hline Jn & $\mathbf{M}$ & 5 & $8.7 \pm 0.2$ & $0.034 \pm 0.004$ & $2.526 \pm 0.313$ & $3.296 \pm 0.188$ & $0.955 \pm 0.083$ & $10.35 \pm 0.29$ & $17.85 \pm 0.50$ \\
\hline $\mathrm{Oc}$ & $\mathbf{F}$ & $11(12)$ & $11.0 \pm 0.5$ & $0.284 \pm 0.016$ & $4.053 \pm 0.349$ & $2.147 \pm 0.204$ & $0.715 \pm 0.089$ & $14.83 \pm 0.78$ & $20.51 \pm 0.93$ \\
\hline$O c$ & $\mathbf{M}$ & $6(12)$ & $5.8 \pm 0.4$ & $0.311 \pm 0.010$ & $4.540 \pm 0.463$ & $2.177 \pm 0.275$ & $0.829 \pm 0.054$ & $16.18 \pm 0.90$ & $21.77 \pm 1.56$ \\
\hline$F$ & & & 14.76 & 114.8 & 23.29 & 14.12 & NS & $15 . \overline{4} 7$ & $5.1 \overline{99}$ \\
\hline$P$ & & & $<0.001$ & $<0.001$ & $<0.001$ & $<0.001$ & & $<0.001$ & 0.012 \\
\hline$r^{2}$ & & & 0.793 & 0.887 & 0.628 & 0.504 & & 0.662 & 0.294 \\
\hline
\end{tabular}

$\mathbf{F}=$ female, $\mathrm{S}=\operatorname{sex}, \mathbf{M}=$ Male; Mo = Month; $(\mathrm{Mr}=\mathrm{March}, \mathrm{Jn}=\mathrm{June}, \mathrm{Oc}=$ October), $N=$ samples analysed, while values in parentheses are numbers of individuals used, if different from sample size. Values shown are arithmetic means \pm standard errors. Results of a two-way ANOVA (by season and sex) are given at the bottom of the table for season only. For each analysis, df for season $=2$, sex $=1$, season $\times$ sex interaction $=2$ and error $=30$. There were no significant season $\times$ sex interactions. Sex is only significant for potassium level and DM (F $=9.189, P=0.005 ;$ and $\mathrm{F}=90.55, P<0.001$, respectively).

than whole insects, e.g. Phyllophaga rugosa $(\mathrm{t}=3.58$, $\mathrm{df}:=24, P<0.01$ ) as shown in Table 4 . Table 4 also shows element composition data in some other whole and culled insects. Although culling reduces biomass consumed/insect, no differences in elemental composition were found for periodical cicadas, Magicicada septemdecim, of either sex. In the moth, Crambus laqueatellus, culling increases the nutrient density of $\mathrm{Fe}, \mathrm{Ca}$ and $\mathrm{Na}$. In June beetles, Phyllophaga rugosa, culling increases the nutrient density of $\mathrm{Mg}, \mathrm{Na}$ and $K$. No pattern of nutrient modification is observable in the few species studied, except for the possibility that culling increases nutrient density for some elements.

\section{Nu'ritional value of insects}

Data reported here may have certain nutritional implications for insectivorous birds and mammals. These implications are based on the assumption that minimal nutritional requirements for growth and reproduction reported for birds (National Research Council, 1984) and mammals (National Research Council, 1978) are typical for all birds and mammals. Requirements for less than a dozen species of birds and mammals are summarized in those references and none of the species studied are primarily insectivorous. Ongoing research (as yet, unpublished) in our laboratory with nestling eastern bluebirds (Sialia sialis) suggests that their requirements for $\mathrm{Na}^{+}$are slightly higher, $\mathbf{K}^{+}$are typical, iron and $\mathbf{M g}^{2+}$ are slightly less, and $\mathrm{N}$ and $\mathrm{Ca}^{2+}$ are markedly less than reported previously for larger, non-insectivorous birds (National Research Council, 1984). We must also assume that data on composition of the insects reported here are typical for all insects. Although data on a wide variety of adult, flying insects are reported in this study, considering the massive numbers of known insect species, acceptance of this second assumption must be tentative.

Subject to the above assumptions, adult flying insects are excellent sources of nitrogen, potassium and magnesium and should readily exceed minimal requirements for growth and reproduction in birds and mammals. For iron and sodium, the extreme variability of levels of those elements in flying insects suggests that some species are excellent nutritional sources while other species are certainly inadequate. No day-flying insects meet published nutritional requirements for calcium for birds or mammals and, of night-flying insects, only plecopterans (stone flies) meet or exceed those requirements. Exclusive ingestion of a readily available, easily captured insect species by pregnant big brown bats, then, should not be expected to meet all nutritional requirements (Kecler and Studier, 1992). Flying insects, then, do not generally fulfill all nutritional requirements for growth and reproduction in birds and mammals. Growing or reproductively active inscctivorous birds and mammals should, therefore, be expected to supplement their insect diet with non-insect sources of deficient nutrients, especially calcium, e.g. grit to meet calcium needs in nestling birds (Turner, 1982), utilization of stored skeletal calcium during pregnancy and lactation in bats (Sevick and Studier, 1992), ingestion of certain non-insect arthropods or other invertebrates which are high in calcium (Reichle et al., 1969; Carter and Cragg, 1976) or cocoons of certain lepidopterans (Studier et al., 1991). Insectivorous time-minimizers would, almost surely, be malnourished in respect to some non-caloric nutrients.

Finally, all of the previous discussion of nutritional requirements applies only to birds and mammals

Table 4. Live mass, percentage body water and element levels (as parts per thousand or percent dry mass) in whole and culled (C) individuals of three species (Sp): Magicicada septemdecim (Ms), Crambus laqueatellus (Cl), and Phyllophaga rugosa (Pr) by sex(s)

\begin{tabular}{|c|c|c|c|c|c|c|c|c|c|c|}
\hline Sp & $\mathbf{S}$ & $N$ & $\begin{array}{c}\text { Mass } \\
(\mathbf{g})\end{array}$ & $\begin{array}{c}\text { Water } \\
(\%)\end{array}$ & $\begin{array}{c}\mathrm{Fe} \\
(\mathrm{ppt})\end{array}$ & $\begin{array}{c}\mathrm{Ca} \\
\text { (ppt) }\end{array}$ & $\begin{array}{c}\mathrm{Mg} \\
(\mathrm{ppt})\end{array}$ & $\begin{array}{c}\mathrm{Na} \\
(\mathrm{ppt})\end{array}$ & $\underset{\text { (ppt) }}{K}$ & $\begin{array}{c}\mathrm{N} \\
(\%)\end{array}$ \\
\hline Ms & $\mathbf{F}$ & 15 & $0.9549 \pm 0.0399 *$ & $52.32 \pm 1.15$ & $0.420 \pm 0.025$ & $1.503 \pm 0.109$ & $1.520 \pm 0.080$ & $0.641 \pm 0.039$ & $5.89 \pm 0.18$ & $9.22 \pm 0.38$ \\
\hline $\mathrm{MsC}$ & $\mathbf{F}$ & 10 & $0.7067 \pm 0.0202^{*}$ & $53.67 \pm 2.35$ & $0.614 \pm 0.091$ & $2.097 \pm 0.331$ & $1.874 \pm 0.216$ & $0.632 \pm 0.060$ & $5.84 \pm 0.36$ & $9.46 \pm 0.75$ \\
\hline Ms & M & 15 & $0.6947 \pm 0.0201$ & $62.98 \pm 1.18$ & $0.692 \pm 0.063$ & $1.188 \pm 0.056$ & $1.950 \pm 0.077$ & $1.028 \pm 0.050$ & $8.35 \pm 0.62$ & $12.20 \pm 0.59$ \\
\hline $\mathrm{MsC}$ & $\mathbf{M}$ & 10 & $0.5590 \pm 0.0204$ & $63.46 \pm 0.89$ & $0.723 \pm 0.050$ & $1.051 \pm 0.033$ & $2.006 \pm 0.056$ & $0.739 \pm 0.073$ & $8.54 \pm 0.40$ & $12.61 \pm 0.58$ \\
\hline $\mathrm{Cl}$ & $\mathrm{U}$ & 15 & $0.0958 \pm 0.0042$ & $58.69 \pm 0.97$ & $0.061 \pm 0.016^{*}$ & $0.267 \pm 0.019^{*}$ & $1.119 \pm 0.058$ & $0.015 \pm 0.009^{*}$ & $7.08 \pm 0.21$ & $15.99 \pm 0.76$ \\
\hline $\mathrm{ClC}$ & U & 4 & $0.0900 \pm 0.0186$ & $59.53 \pm 3.24$ & $0.521 \pm 0.089^{*}$ & $0.504 \pm 0.035^{*}$ & $1.201 \pm 0.211$ & $0.205 \pm 0.041^{*}$ & $7.27 \pm 0.80$ & $13.45 \pm 0.92$ \\
\hline Pr & $\mathbf{U}$ & 15 & $0.3034 \pm 0.0126$ & $67.27 \pm 0.95^{*}$ & $0.168 \pm 0.010$ & $0.432 \pm 0.073$ & $1.898 \pm 0.057^{*}$ & $0.787 \pm 0.024^{*}$ & $11.51 \pm 0.22^{*}$ & $13.16 \pm 0.34$ \\
\hline PrC & U & 11 & $0.2854 \pm 0.0211$ & $71.79 \pm 0.83^{*}$ & $0.206 \pm 0.025$ & $0.456 \pm 0.060$ & $2.637 \pm 0.147$ & $1.348 \pm 0.054^{*}$ & $15.06 \pm 0.74$ & $14.27 \pm 0.58$ \\
\hline
\end{tabular}

$\mathrm{S}=$ Sex, $\mathrm{F}=$ female, $\mathrm{M}=$ male, $\mathrm{U}=$ unknown, $N=$ samples analysed. Pairs marked * are significantly different by independent $t$-tests at $P<0.05$, after adjustment in accord with the Bonferroni method. 
during periods of growth or reproductive activity. Although we have found no data for non-reproductively active adults, their maintenance requirements would certainly be less than those of growing or reproductively active individuals. Insects may well be complete nutritional sources during such non-reproductive periods in adult birds and mammals.

Acknowledgements - These studies were supported in part by a Faculty Development Fund Grant from The University of Michigan-Flint. We thank Ms Caroline Forbush, $\mathrm{Mr}$ and Mrs Ron Gregor, $\mathrm{Mr}$ and Mrs Dennis Viele $\mathrm{Sr}$ and, especially, $\mathrm{Mr}$ and Mrs Kenneth Clark for permission to collect on their property. We thank the public officials of Byron, MI and Genesee Co., MI, and the directors of Skyline Camp, Lapeer Co., MI for permission to collect on land under their control. We especially thank Dr T. Poulson for collecting and shipping us the cicadas. Dr S. Szczytko graciously identified the Perlesta decipiens. We very gratefully thank Margaret C. Rummel, Vickie M. Yott, Lee J. Yott, Dennis P. Viele Jr, Fern Gregor, Ann Studier, Grant Hogle, Lynne Latra, Joanne DeVoll, Chris Sherman, Kathy Lavoie, John Sherwood, Libbi Mason, Larry Atherton, Cathy Sevick, Mary Ann Cardani, Kevin Cardani, John Fitzgibbons and, especially, John $\mathrm{O}$. Keeler for their aid in both field and lab aspects of this study. We are especially grateful for the understanding and patience shown by Cathy Sevick and Ann Studier. Drs M. Scriber, 'T. Kunz, K. Lavoie and R. Schenck provided useful comments on this manuscript.

\section{REFERENCES}

Arms K., Feeny P. and Lederhouse R. (1974) Sodium: stimulus for puddling behavior by swallowtail butterflies, Papilio glaucus, Science 185, 372-374.

Arnett R. H. Hr (1985) American Insects. Von Nostrand Reinhold Co., New York.

Beck M. and Galef B. G. Jr (1989) Social influences on the selection of a protein-sufficient diet by Norway rats (Rattus norvegicus). J. comp. Psychol. 103, 132-139.

Bell G. P. (1982) Behavioral and ecological aspects of gleaning by a desert insectivorous bat, Antrozous pallidus (Chiroptera: Vespertilionidae). Behav. Ecol. Sociobiol. 10, 217-223.

Belovsky G. E. (1981) Optimal activity times and habitat choice of moose. Oecologia 48, 22-30.

Belovsky G. E. (1984) Herbivore optimal foraging: a comparative test of three models. Am. Nat. 124, 97-115.

Belovsky G. E., Ritchie M. E. and Moorehead J. (1989) Foraging in complex environments: when prey availability varies over time and space. Theoret. Pop. Biol. 36, 144-160.

Blatchley W. S. (1920) Orthoptera of Northeastern America. The Nature Publishing Co., Indianapolis, IN.

Bowden J., Digby P. G. N. and Sherlock P. L. (1984) Studies of elemental composition as a biological marker in insects. I. the influence of soil type and host-plant on elemental composition of Noctua pronuba (L). (Lepidoptera: Noctuidae). Bull. Ent. Res. 74, 207-225.

Cantrall I. J. (1943) The Ecology of the Orthoptera and Dermaptera of the George Reserve, Michigan. University of Michigan Press, Ann Arbor, MI.

Cantrall I. J. (1968) An annotated list of the Dermaptera, Dictyoptera, Phasmatoptera, and Orthoptera of Michigan. The Michigan Entomologist 1, 299-346.

Carter A. and Cragg J. B. (1976) Concentrations and standing crops of calcium, magnesium and sodium in soil and litter arthropods and their food in an aspen woodland ecosystem in the Rocky Mountains (Canada). Pedobiologia 16, 379-388.
Chariton R. W. and Bothwell T. H. (1983) Iron absorption. Ann. Rev. Med. 34, 55-68.

Clark D. A. (1982) Foraging behavior of a vertebrate omnivore (Rattus rattus): meal structure, sampling, and diet breadth. Ecology 63, 763-772.

Covell C. V. Jr (1984) A Field Guide to the Moths of Eastern North America. Houghton Mifflin Co., Boston, MA.

Cummins K. W. and Wuycheck J. C. (1971) Caloric equivalents for investigation in ecological energetics. Mitt. Int. Verein. Limnol. 18, 1-158.

Edmunds G. F. Jr and Jensen S. L. (1976) The Mayflies of North and Central America. University of Minnesota Press, Minneapolis, MI.

Ehrlich P. R., Dobkin D. S. and Wheye D. (1988) The Birder's Guide. Simon and Schuster, New York.

Galef B. G. Jr (1991) A contrarian view of the wisdom of the body as it relates to dietary self-selection. Psychol. Rev. 98, 218-223.

Gardner A. L. (1977) Feeding habits. In Biology of Bats of the New World Family Phyllostomatidae. Part II (Edited by Baker R. J., Jones J. K. Jr and Carter D. C.), pp. 293-350. Specialist Publications Museum, Texas Technical University, TX.

Gurney A. B. and Brooks A. R. (1959) Grasshoppers of the Mexicanus group, genus Melanoplus (Orthoptera: Acrididae). Proc. U. S. National Museum 110, 1-93.

Jones P. J. (1976) The utilization of calcareous grit by laying Q. quelea. Ibis 118, 575-576.

Keeler J. O. and Studier E. H. (1992) Nutrition in pregnant big brown bats (Eptesicus fuscus) feeding on June beetles. J. Mammal. 73, 426-430

Krebs J. R. (1978) Optimal foraging: decision rules for predators. In Behavioral Ecology: An Evolutionary Approach (Edited by Krebs J. R. and Davies N. B.) Blackwell, Oxford.

Krebs J. R. (1980) Optimal foraging, predation risk, and territory defense. Ardea 68, 83-90.

Leonard J. W. and Leonard F. A. (1962) Mayflies of Michigan Trout Streams. Cranbrook Institute of Science, Bloomfield Hills, MI.

Levy R. and Cromroy H. L. (1973) Concentration of some major and trace elements in forty-one species of adult and immature insects determined by atomic absorption spectroscopy. Ann. Entl. Soc. Am. 66, 523-526.

Maclean S. F. (1974) Lemming bones as a source of calcium for artic sandpipers (Calidris spp). Ibis 116, 552-557.

Mattson W. J. and Scriber J. M. (1987) Nutritional ecology of insect folivores of woody plants: nitrogen, water, fiber and mineral considerations. Ch. 3. In Nutritional Ecology of Insects, Mites and Spiders (Edited by Slansky F. and Rodriguez J. G.), pp. 105-146. John Wiley and Sons, New York.

McCafferty W. P. (1981) Aquatic Ecology. Science Books Int., Boston, MA.

Meyer J. H., Grunert R. R., Zepplin M. T., Grummer R. H., Bohstedt G. and Phillips P. H. (1950) Effect of dietary levels of sodium and potassium on growth and on concentrations in blood plasma and tissues of the white rat. $\mathrm{Am}$. J. Physiol. 162, 182-188.

Milne L. and Milne M. (1980) The Audobon Society Field Guide to North American Insects and Spiders. Alfred A. Knopf, New York.

National Research Council (1978) Nutrient Requirements of Laboratory Animals, No. 10, 3rd edition. National Academy of Sciences, Washington, DC.

National Research Council (1984) Nutrient Requirements of Poultry, 8th edition. National Academy of Sciences, Washington, DC.

Necdham J. G. and Westfall M. J. Jr (1955) A Manual of the Dragonflies of North America. University of California Press, Berkeley, CA.

Peters R. H. (1983) The Ecological Implications of Body Size. Cambridge University Press, Cambridge, U.K. 
Pulliam H. R. (1975) Diet optimization with nutrient constraines. Am. Nat. 109, 765-768.

Pyke G. H. (1984) Optimal foraging theory: a critical review. Ann. Rev. Ecol. Syst. 15, 523-575.

Pyke G. H., Pulliam H. R. and Charnov E. L. (1977) Optimal foraging: a selective review of theory and tests. Q. Rev. Biol. 52, 137-154.

Pyle R. M. (1981) The Audobon Society Field Guide to North American Butterflies. Alfred A. Knopf, New York.

Re chle D. E., Shanks M. H. and Crossley D. A. Jr (1969) Calcium, potassium and sodium content of forest floor arthropods. Ann. Entl. Soc. Am. 62, $\leq 7-62$.

Repasky R. R., Blue R. J. and Doerr P. D. (1991) Laying red-cockaded woodpeckers cache bone fragments. Condor 93, 458-461.

Scl oener T. W. (1971) Theory of feeding strategies. Ann. Rev. Ecol. Syst. 11, 369-404.

Scloener T. W. (1979) Generality of the size-distance relation in models of optimal feeding. Am. Nat. 114, S.02-914.

Scl owalter T. D., Webb J. W. and Crossley D. A. Jr (1981) Community structure and nutrient content of canopy arthropods in clearcut and uncut forest systems. Ecology 62, 1010-1019.

Sch roeder L. (1977) Distribution of caloric densities among lirvae feeding on black cherry leaves. Oecologia 29, 219-222.

Sevick S. H. and Studier E. H. (1992) Change in forearm curvature throughout the summer in female big brown bats. J. Mammal. (in press).

Sla asky F. Jr and Scriber J. M. (1985) Food consumption. In Comprehensive Insect Physiology, Biochemistry and Pharmacology (Edited by Kerkut G. A. and Gilbert L. I.), Vol. 4, pp. 87-162. Pergamon Press, Oxford.
Staaland H., White R. G., Luick J. R. and Hollman D. F. (1980) Dietary influences on sodium and potassium metabolism of reindeer. Can. J. Zool. 58, 1728-1734.

Stamps J., Tanaka S. and Krishnan V. V. (1981) The relationship between selectivity and food abundance in a juvenile lizard. Ecology 62, 1079-1092.

Studier E. H., Keeler J. O. and Sevick S. H. (1991) Nutrient composition of caterpillars, pupae, cocoons and adults of the eastern tent moth, Malacosoma americanum (Lepidoptera: Lasiocampidae). Comp. Biochem. Physiol. 100A, 1041-1043.

Sullivan K. A. (1988) Age-specific profitability and prey choice. Anim. Behav. 36, 613-615.

Sullivan K. A. (1989) Predation and starvation: age-specific mortality in juvenile juncos (Junco phaenotus). J. Anim. Ecol. 58, 275-286.

Treybig D. S. and Haney P. L. (1983) Colorimetric determination of total nitrogens in amines with selenium catalyst. Analyt. Chem. 55, 983-985.

Turner A. K. (1982) Timing of laying by swallows (Hirundo rustica) and sand martins (Riparia riparis). J. Anim. Ecol. 51, 29-46.

Vickery W. L. (1984) Optimal diet models and rodent food consumption. Anim. Behav. 32, 340-348.

Weeks H. P. Jr and Kirkpatrick C. M. (1978) Salt preferences and sodium drive phenology in fox squirrels and woodchucks. J. Mammal. 59, 531-542.

Whitaker J. O. Jr (1988) Food habits analysis of insectivorous bats. In Ecological and Behavioral Methods for the Study of Bats (Edited by Kunz T. H.), pp. 171-189. Smithsonian Institution Press, Washington, DC.

White R. E. (1983) A Field Guide to the Beetles of North America. Houghton Mifflin Co., Boston, MA.

Wilkinson L. (1987) SYSTAT: The System for Statistics. SYSTAT, Evanston, IL. 


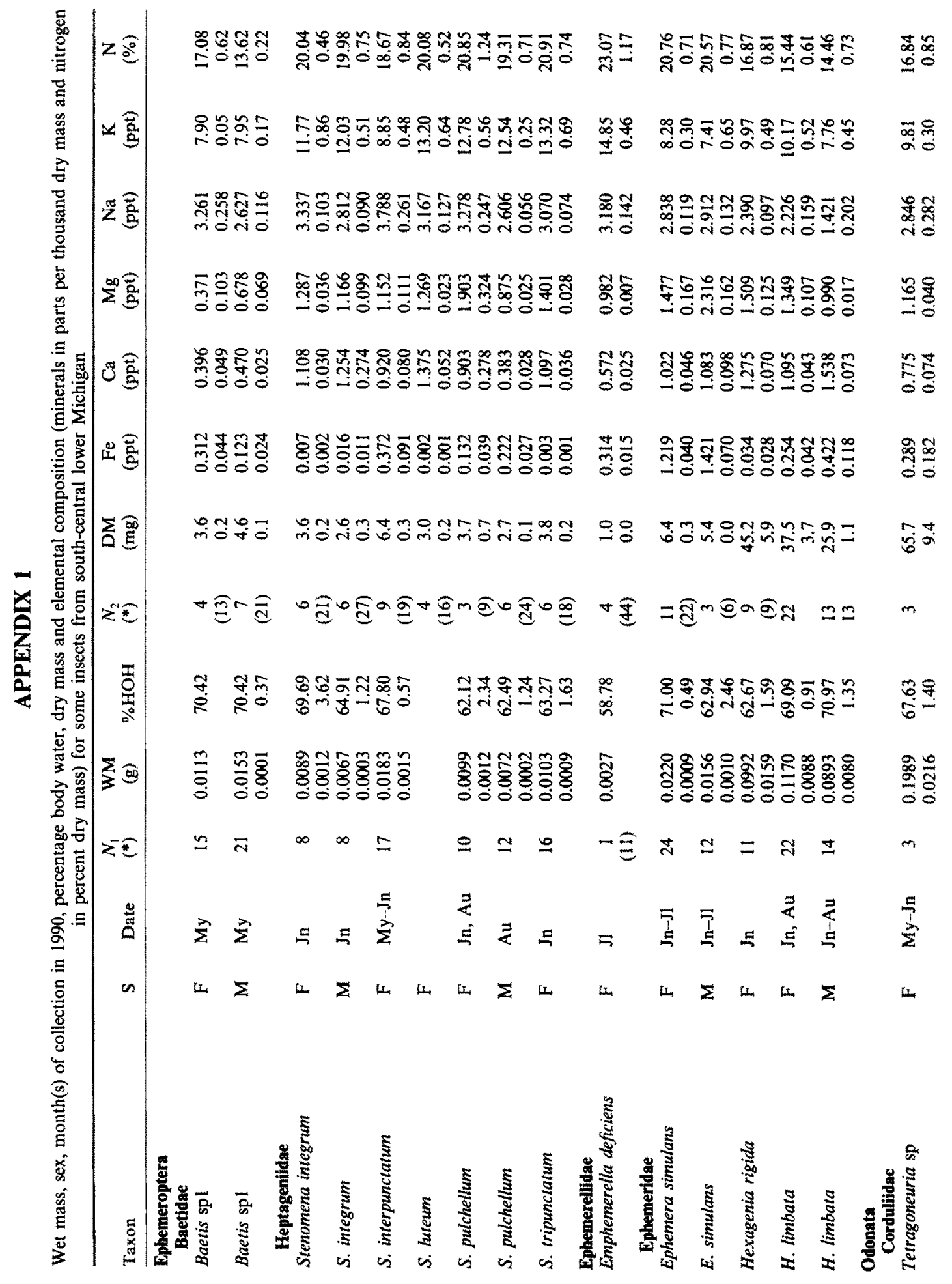




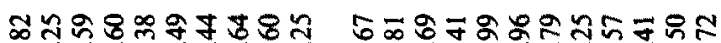

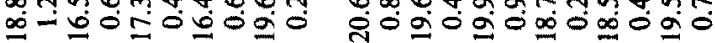

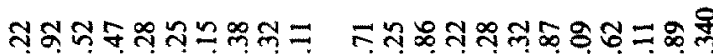

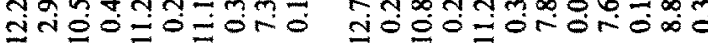

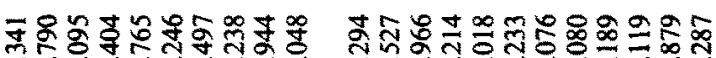

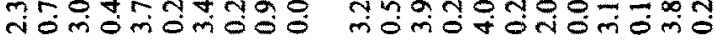

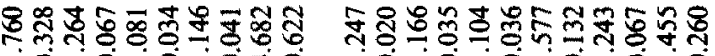

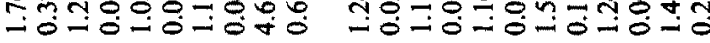

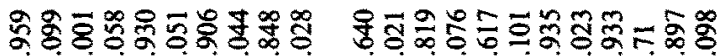

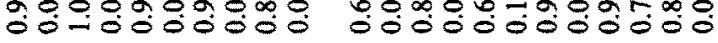

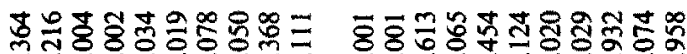

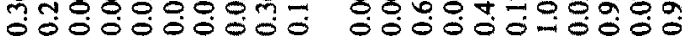

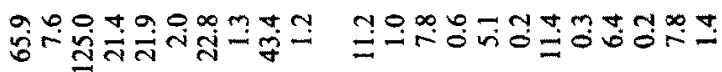

$+\quad \simeq \alpha \simeq$ $r$ $m$ สูก

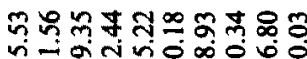

퉁ํำ ๖ํ.-

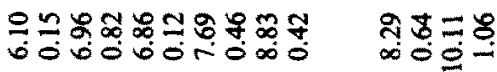

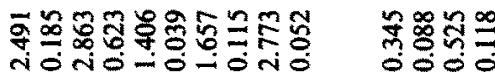

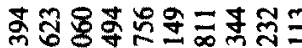

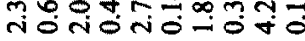

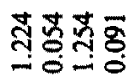

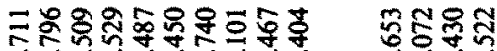

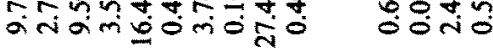

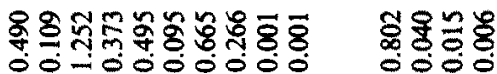

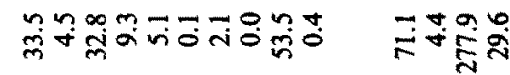

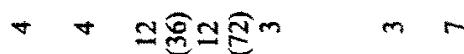

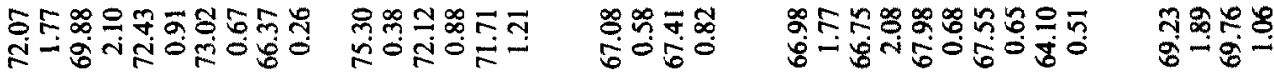

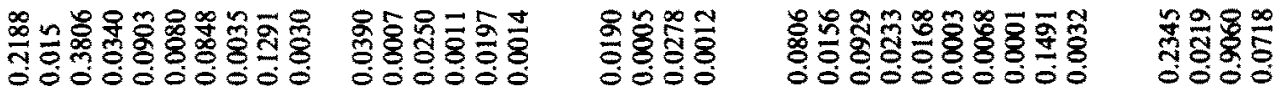
$m \sim \underline{\varrho}=$
$\infty \approx 2$
$\bar{\sim} \approx$

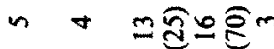

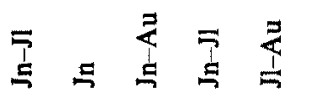
$=\stackrel{5}{\Sigma} \frac{5}{\Sigma}$
$\Xi \Xi$
$\Xi \pm=\Xi \pm$
$\stackrel{5}{5} \stackrel{4}{=}$
山L山 $\Sigma \Sigma$
$L L \sum L \Sigma \Sigma$
L $\Sigma \Sigma \Sigma D$

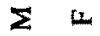

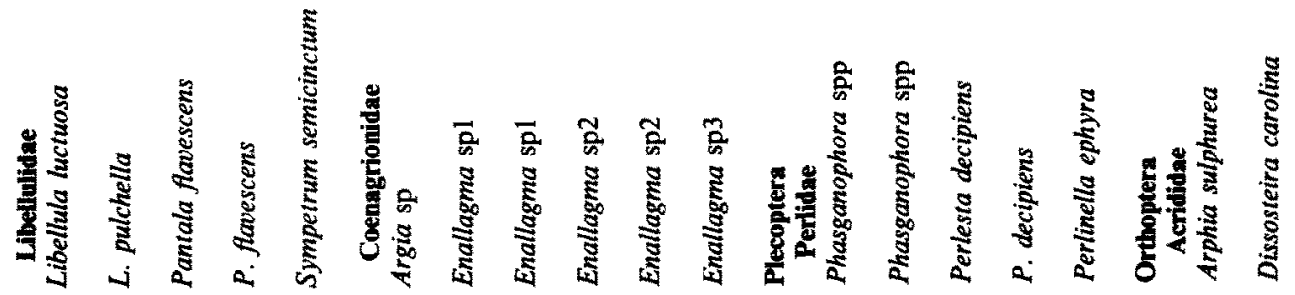




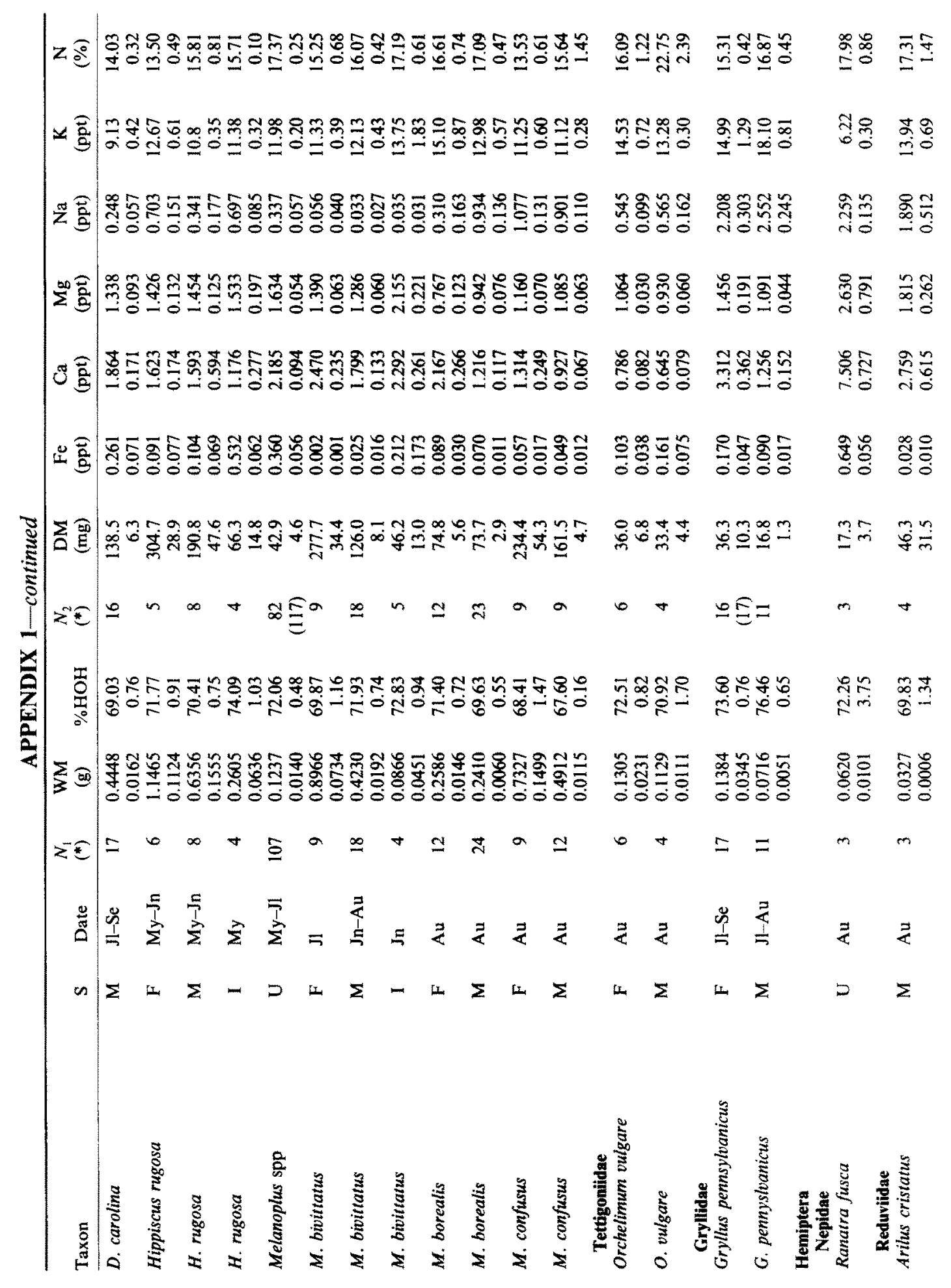




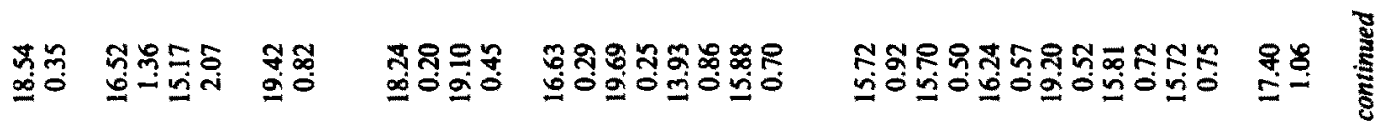

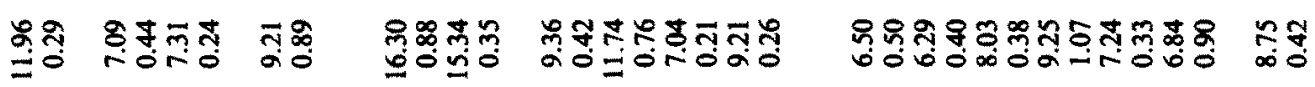

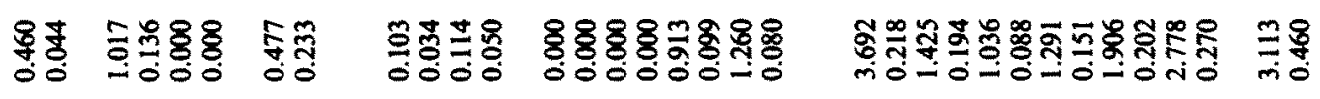

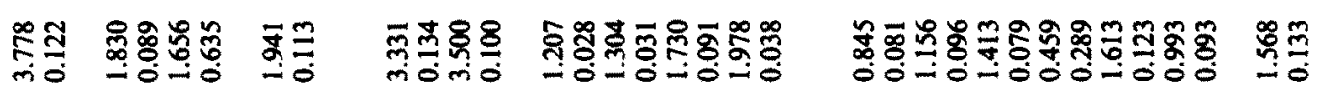

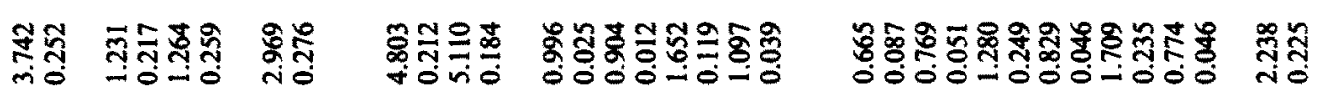

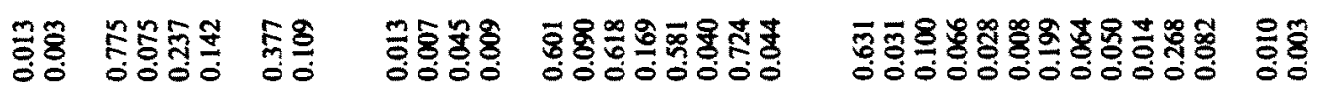

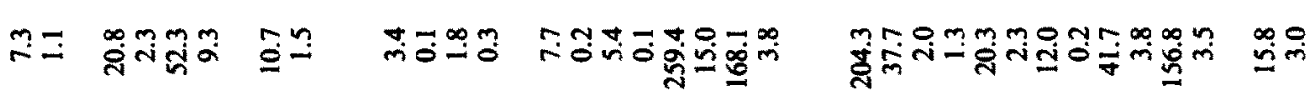

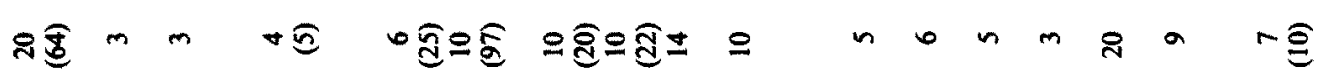

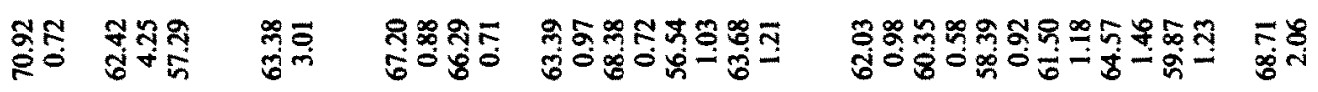

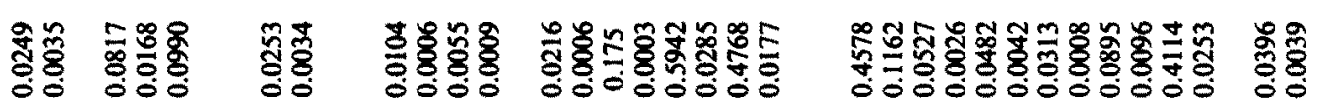

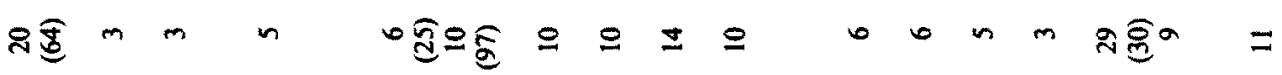

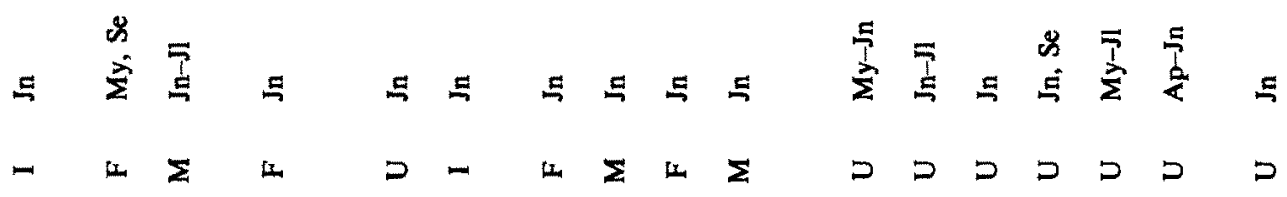

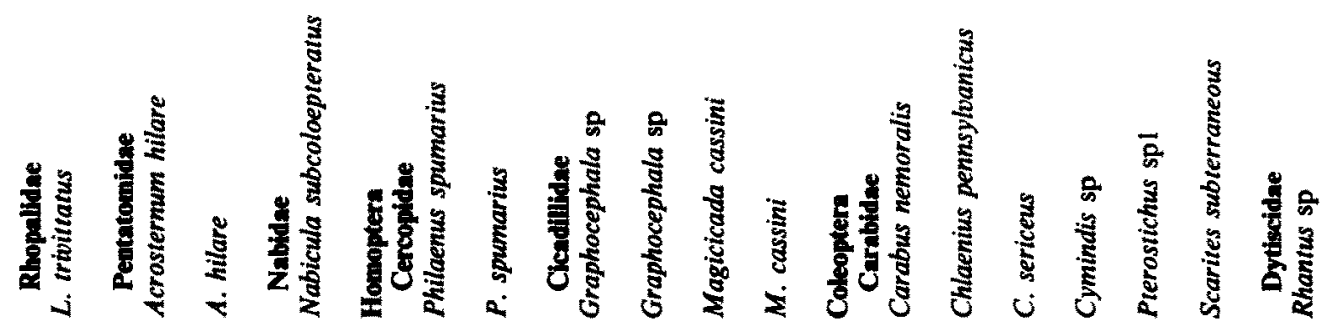


z ×

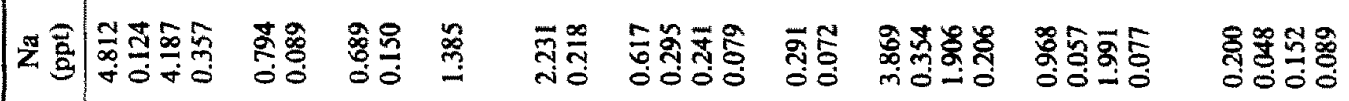

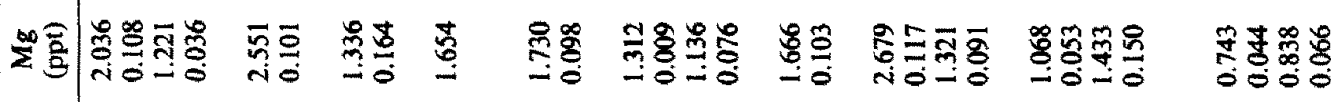

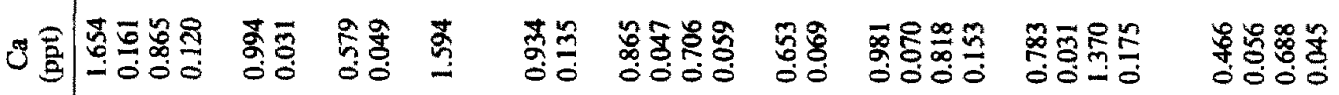

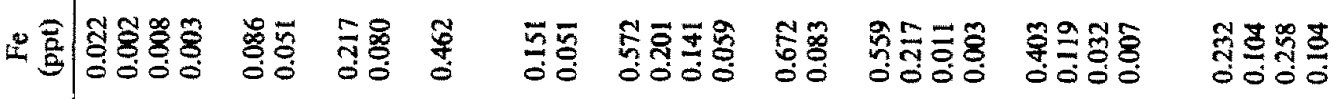

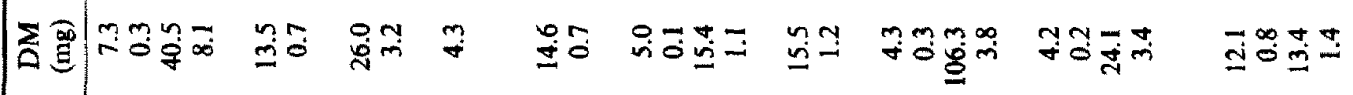

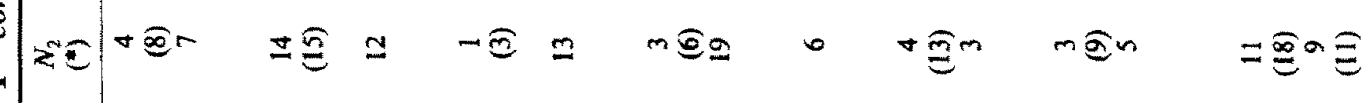

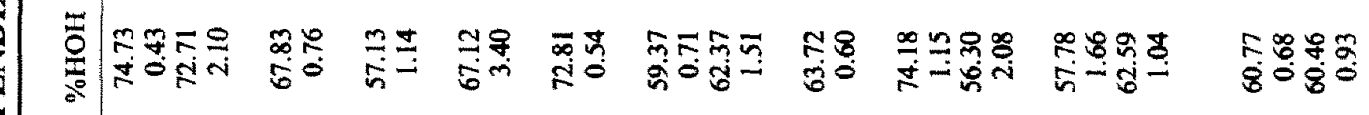

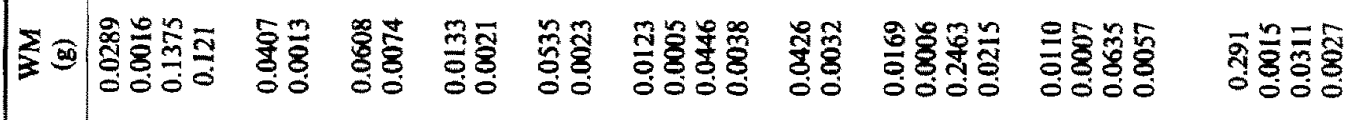

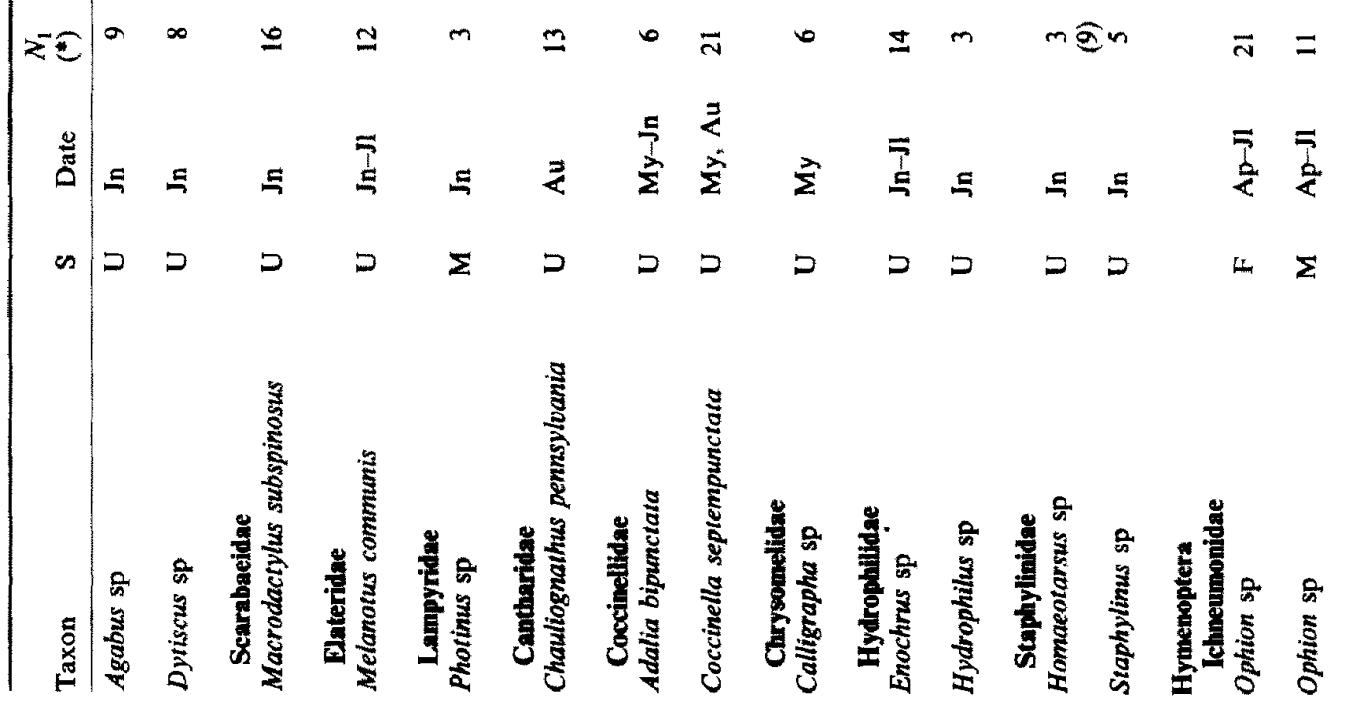




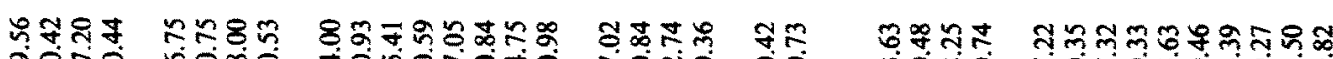

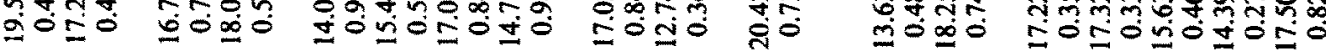

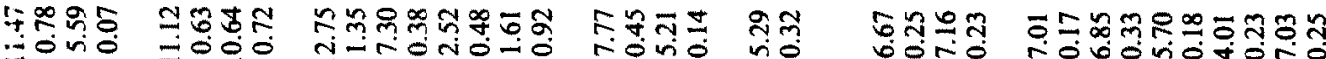

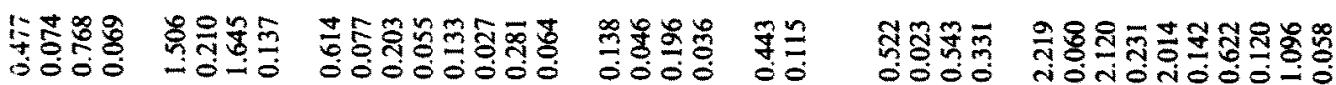

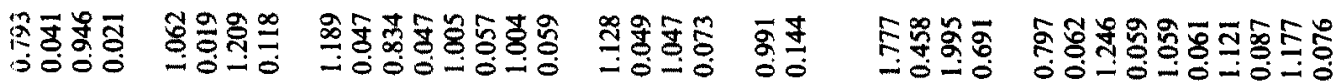

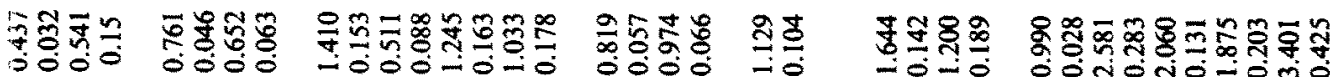

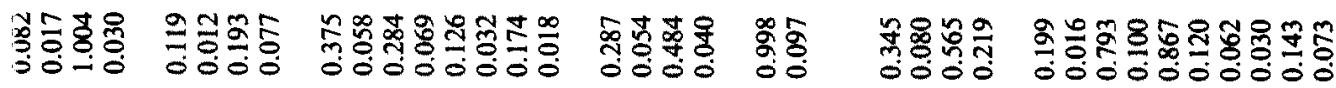

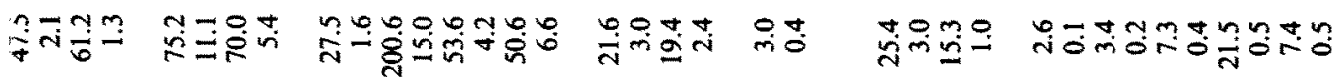

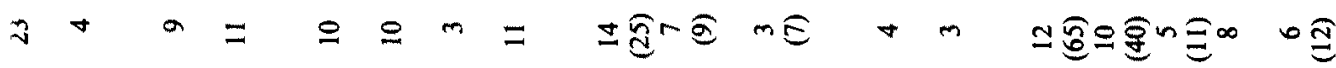

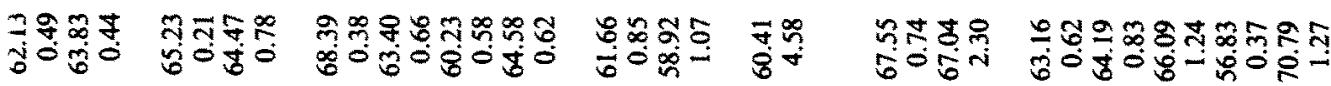

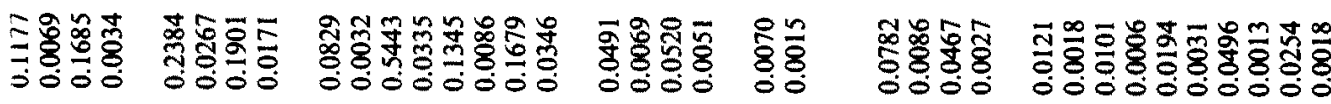

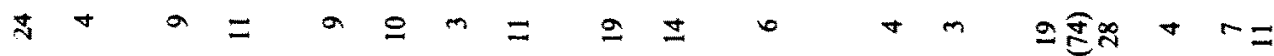

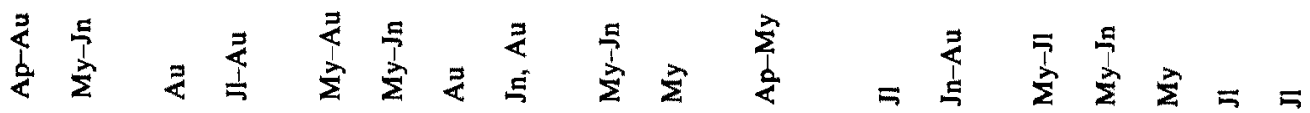

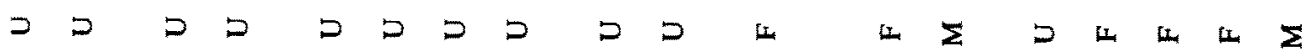

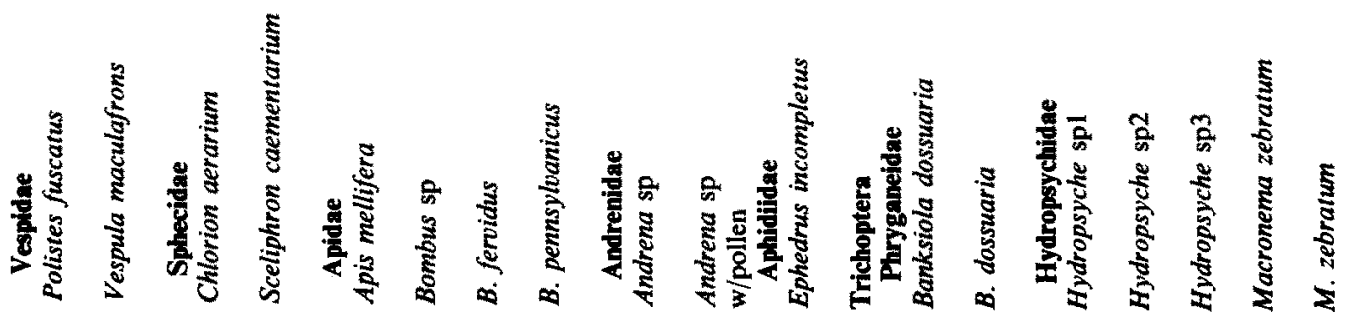




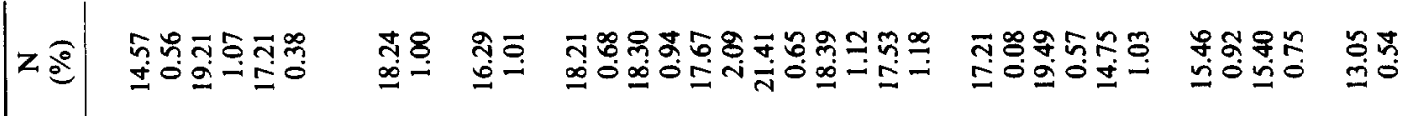 \\ ×

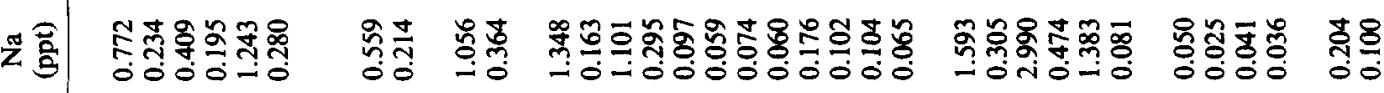

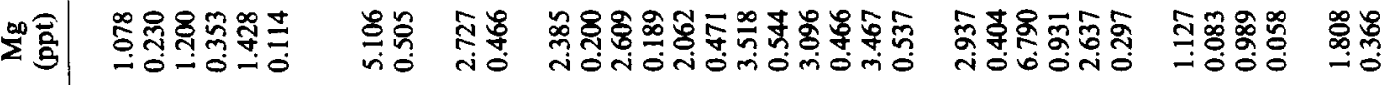

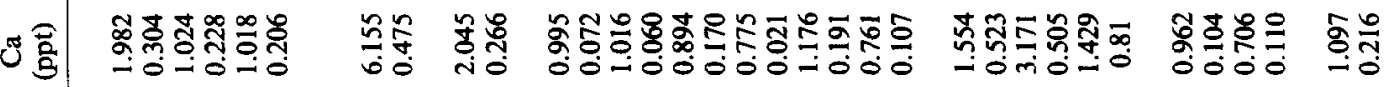

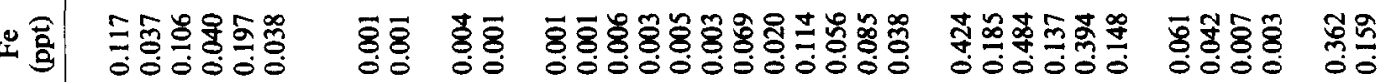

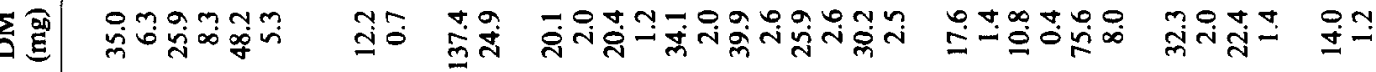

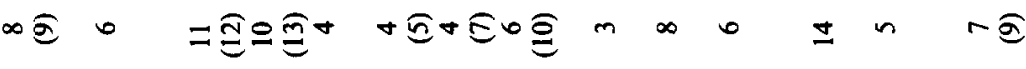

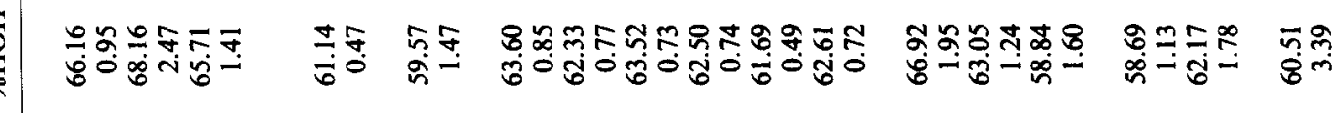

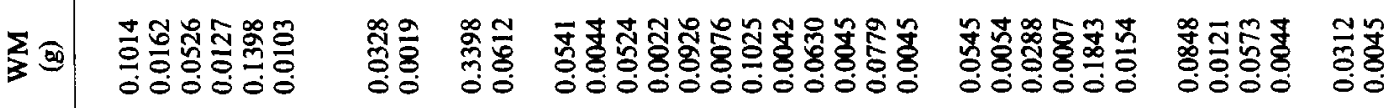

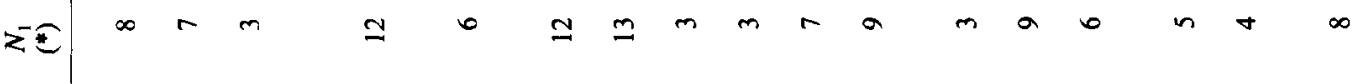

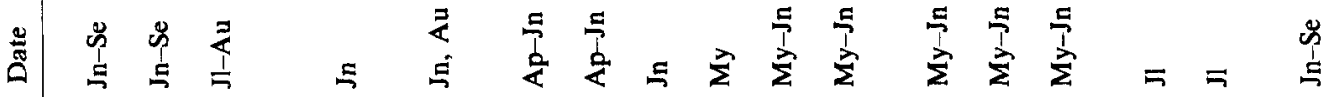

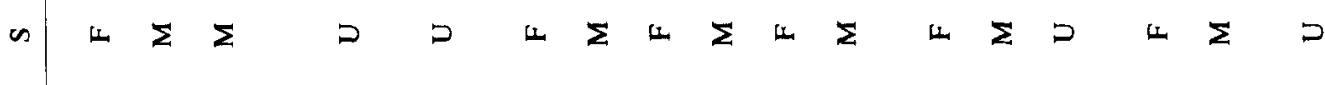




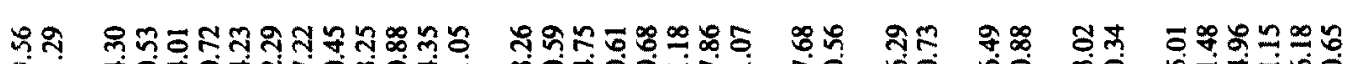

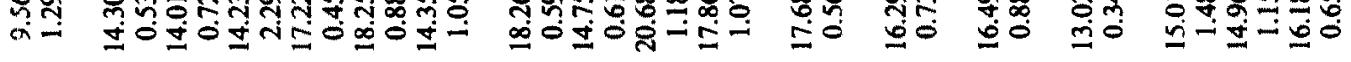

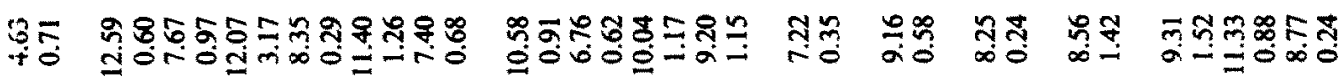

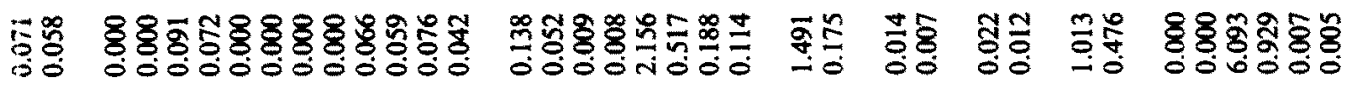

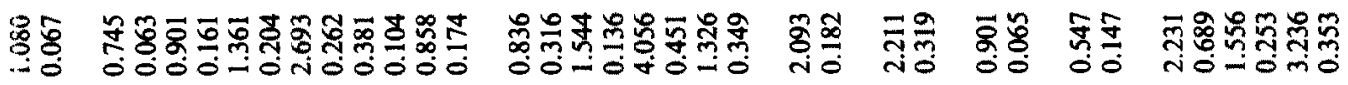

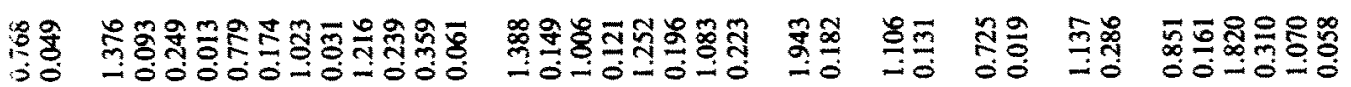

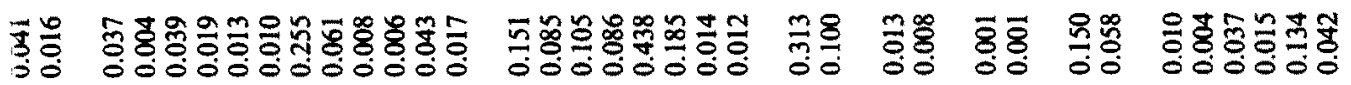

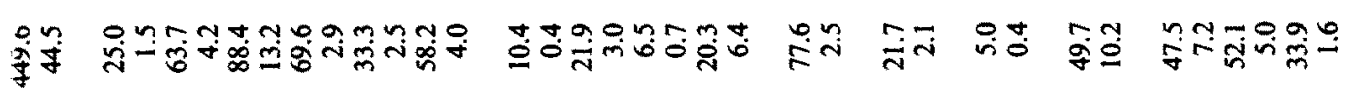

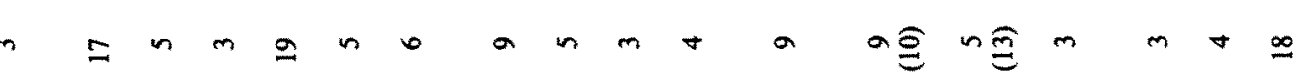

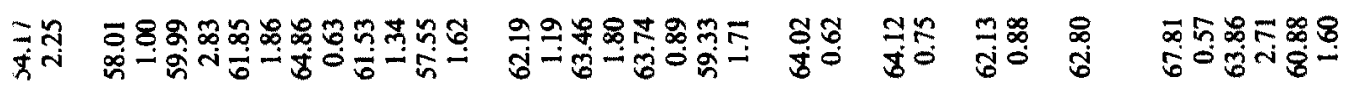

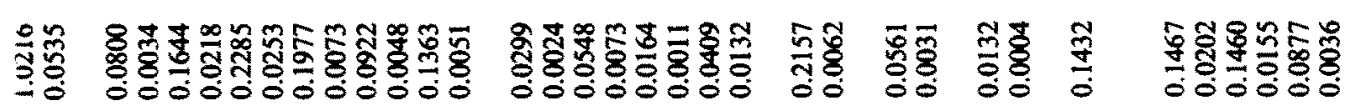

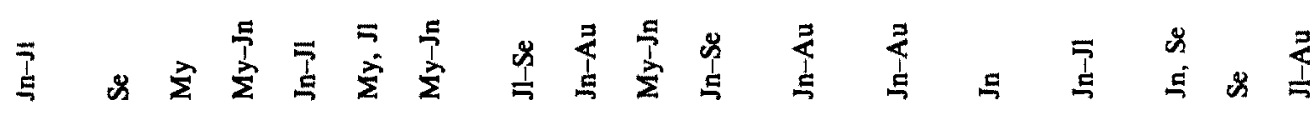
DDEDDDDDDDDDDDDDD

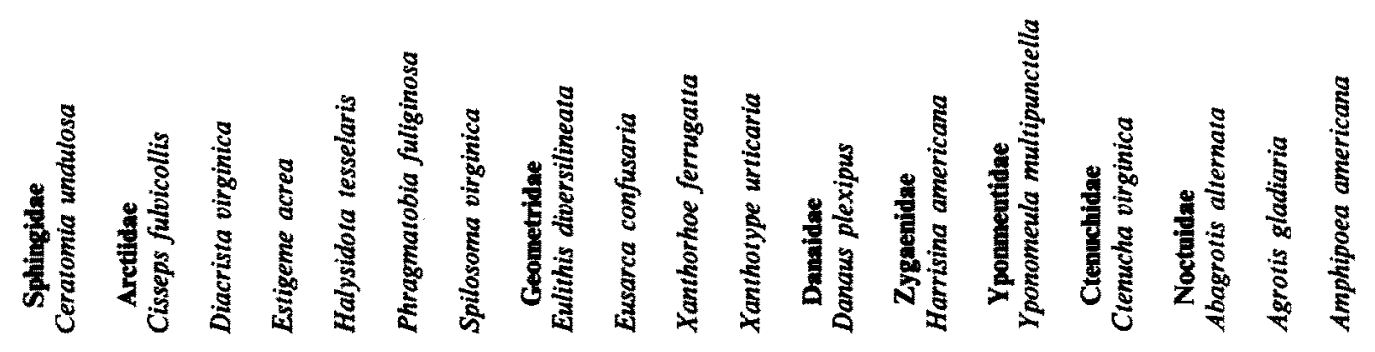




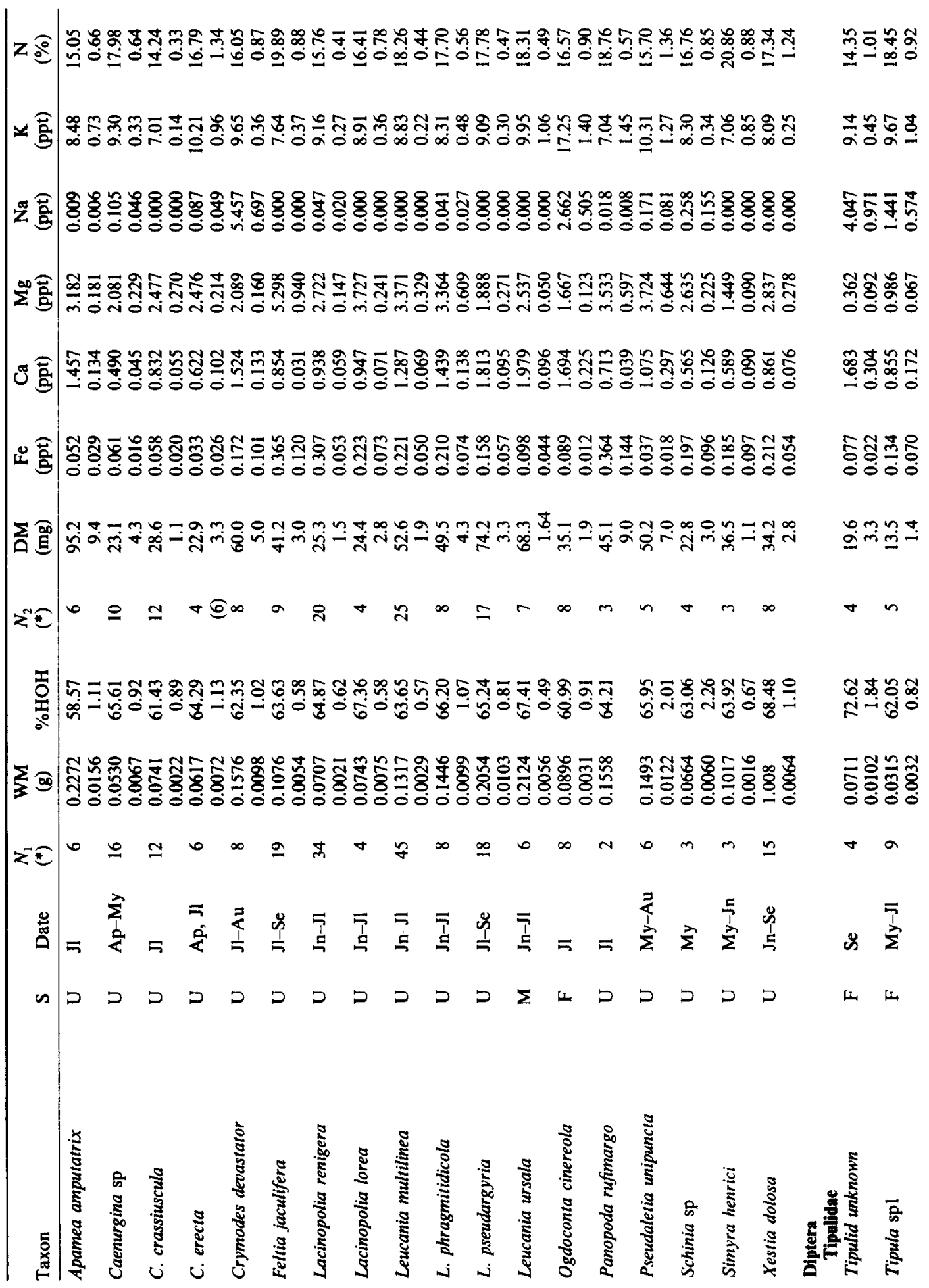




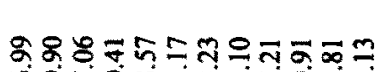

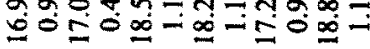

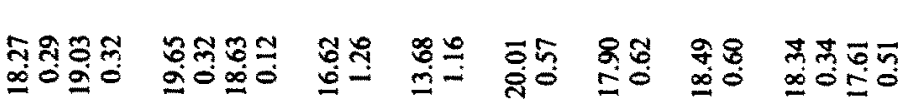

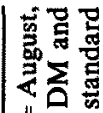

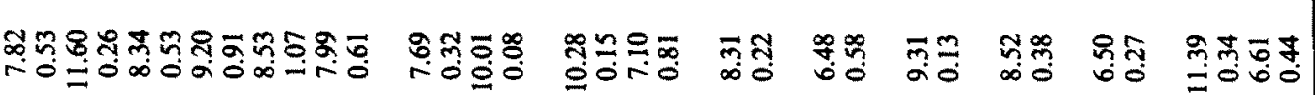

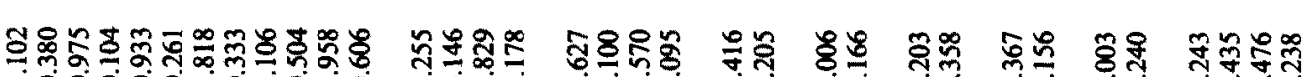

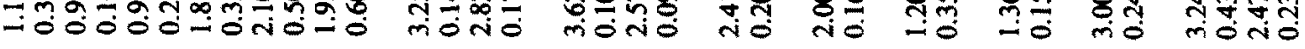

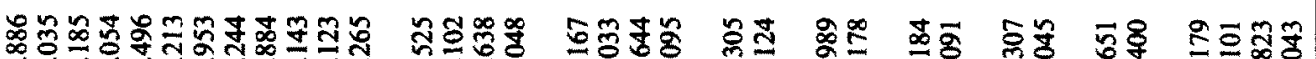

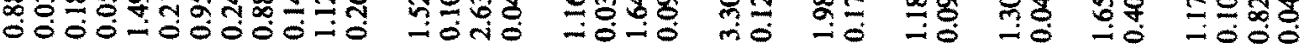

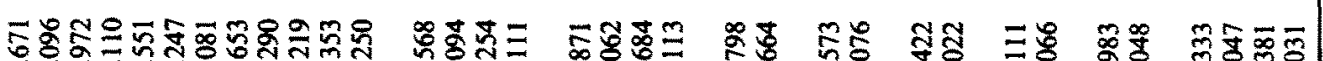

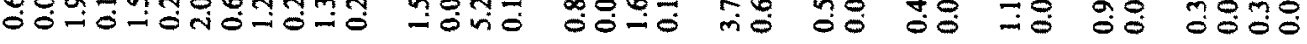

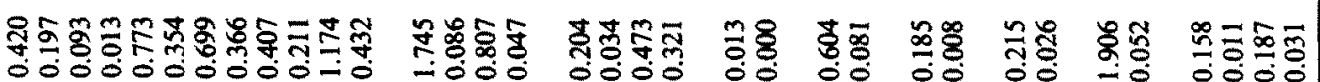

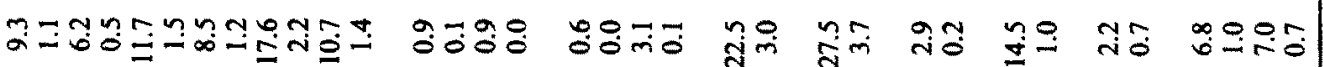

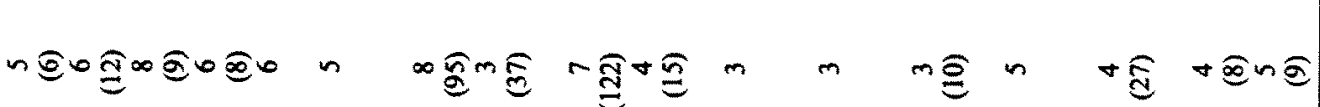

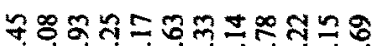

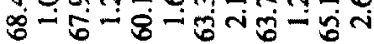

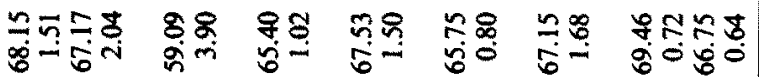

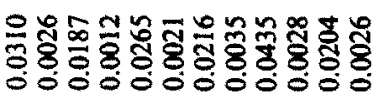

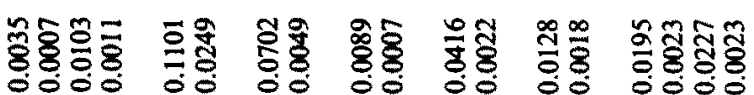
$m \cong \infty \infty n$

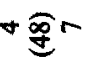

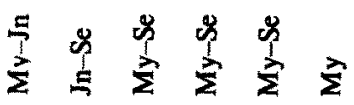

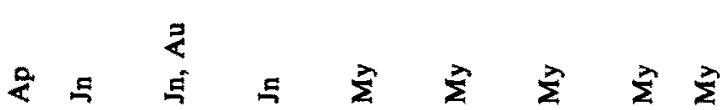

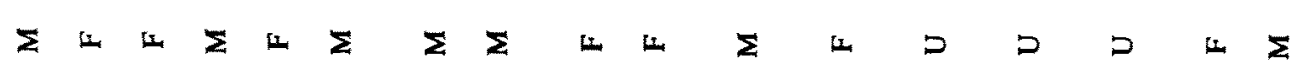

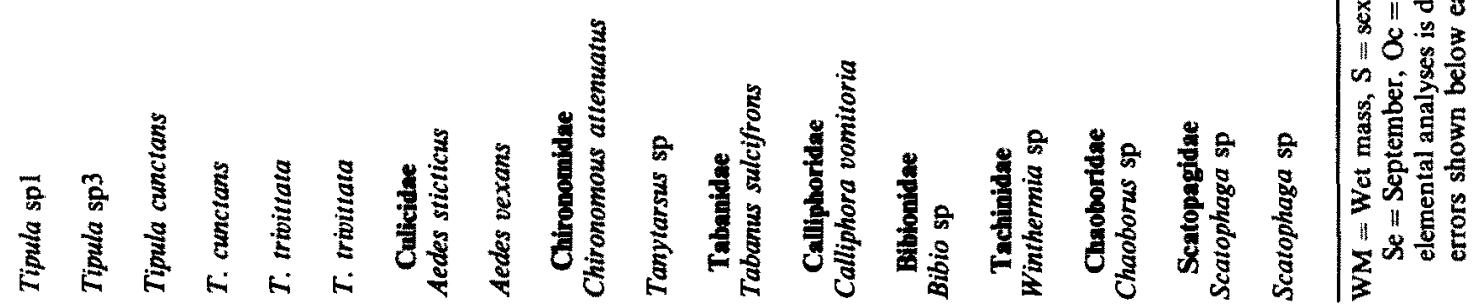

